\title{
Fractionation of Sediment Phosphorus in Lagoon Porto-Novo (Benin Republic) Revisited: Changes in Phosphorus Fractions and Release as Affected by Seasons and Sampling Sites
}

\author{
Henri Kpèdékpo Akogbeto ${ }^{1 *}$, Ahissou Séraphin Zanklan², \\ Edmond Sossoukpe ${ }^{3}$ and Emile Didier Fiogbe ${ }^{3}$
}
${ }^{1}$ International Chair in Mathematical Physics and Applications (ICMPA), Faculty of Sciences and Technologies (FAST), University Abomey-Calavi, 072 P.O.Box 50, Cotonou, Benin
${ }^{2}$ Département de Biologie Végétale, Facultédes Sciences et Techniques (FAST), Universitéd'Abomey-Calavi (UAC), 01 BP 4521, Cotonou (République du Bénin)
${ }^{3}$ Unité de Recherche sur les Zones Humides, Département de Zoologie, Faculté des Sciences et Techniques, Université d'Abomey-Calavi, 01BP526 Cotonou, Bénin
*Corresponding author

\begin{tabular}{|c|c|}
\hline & A B S T R A C T \\
\hline & \multirow{5}{*}{$\begin{array}{l}\mathrm{P} \text { is a key factor responsible of continental water eutrophication. In lagoon Porto-Novo } \\
\text { sediments, it arises from slope basin supplies and biological activity. The present study has } \\
\text { the main objective to evaluate phosphorus release rate coming from lagoon sediment, and } \\
\text { to analyse the availability of these nutrient fractions. Four sampling point served to take up } \\
\text { waters and sediments destined to analyses. The first five centimetres of sediments and } \\
\text { waters were used and analyses (sequential extraction method) carried out on fraction } 250 \\
\mu \mathrm{m} \text {, lyophilized for phosphorus fractionation. Phosphorus release rate was calculated } \\
\text { applying Nürnberg regression equations which have been built from PT concentrations } \\
\text { measured in seven Ontario and Connecticut Lake sediments. One-way variance analysis } \\
\text { (ANOVA 1) using Dunnett method and Pearson (r) correlation implemented in MINITAB } \\
\text { and JMP were applied. Results showed different phosphorus forms inside sediment. These } \\
\text { forms were: P-labile, P-Fe, P-Ca, P-Al and P-Org accompanied by P-reside with a rate in } \\
\text { mobilizable phosphorus reaching } 66.39 \% \text { PT. P-Org was the most abundant, attaining } \\
\text { proportion between } 452.6 \pm 53.50 \mu \mathrm{gP} / \mathrm{g}-2035.4 \pm 311.2 \mu \mathrm{gP} / \mathrm{g} \text { of dry sediment, } \\
\text { consequence of organic matter accumulation from slope basin due to diverse human } \\
\text { activities, and animal and plant organic matters present on the watershed. P-Ca is relatively } \\
\text { more found in station S1 and S4 in contrast to S2 and S3. Release rate (TL) registered } \\
\left(11,05 \mathrm{mg} \mathrm{m}^{-2} * \mathrm{j}^{-1} \text { ) indicates then that lagoon Porto-Novo is in a more or less advanced }\right. \\
\text { degradation state with an internal load estimated by } 156,03 \text { mg*m }{ }^{-2} * \text { saison }{ }^{-1} \text {. These results } \\
\text { should be helpful for local and national authorities and stakeholders in setting } \\
\text { environmental policies regarding phosphorus reduction, particularly that flowing from } \\
\text { slope basin. }\end{array}$} \\
\hline $\begin{array}{l}\text { Sequential extraction, } \\
\text { Phosphorus, Release, } \\
\text { Fractionation, Release } \\
\text { rate. }\end{array}$ & \\
\hline Article Info & \\
\hline & \\
\hline & \\
\hline
\end{tabular}

\section{Introduction}

Continental waters as receptor environments ofslope basinaccumulate nutrients from natural as well as anthropoid origins (Oraison et al., 2011). These facts lead to not only an 
eutrophication of the surface waters, but also to that of environments located more downstream. Under temperate zones, the main cause of this increased eutrophication also called cultural eutrophication remains an increment in phosphorus supplies (Pienitz and Vincent, 2003). Similar observation is made in tropical areas with consequence corresponding to the proliferation of macrophytes. According to Gerdes and Kunst (1998), phosphorus is identified as a key nutrient causing eutrophication in continental aquatic areas. It is known as plant growth limiting factor in surface water(Smith et al., 1999) and interrestrial ecosystems (Craaq, 2008).Lagoon phosphorus essentially came from slope basin, and then has terrestrial origin (Hou et al., 2013) on Daihai Lake in Northwest China.

Sediment role in phosphorus cycle and their impact upon lake eutrophication process may be considerable (Golterman, 2004a, 2004b). Hence, comparatively to phosphorus from slope basin which is under dissolved and particle form, released phosphorus from sediment appears exclusively under dissolved form (Nürnberg, 2009). It is therefore totally equitable by living organisms such as phytoplankton, and can stimulate highly lake primary productivity. According to Oraison et al., (2011), nutrients can be immobilized more or less temporally whenever touching sediments. They can be stored perennially whenever combined with other ions present within soil particles (iron, aluminium). Thus, human slope basin exploitation provokes an accumulation of phosphorus in sediments (Labrecque et al., 2012). Actual phosphorus in sediments hinges also upon biological activity running in the lake (Stenzel et al., 2017). It drifts across years and is freed by release phenomenon once some conditions admit it. Water swellings which mobilize sediments may move in suspension nutrients previously fixed in. According to Nürnberg and Lazerte (2004), phosphorus release rate (TL) between 2 and $7 \mathrm{mg} \bullet \mathrm{m}^{-2} \cdot$ jour $^{-1}$ characterize mesotrophic lakes. Evaluation of an area trophic potential depends then on phosphorus concentration in water, and on its sedimentary countenance (Bootsma et al., 1999; Kaiserli et al., 2002).

Although soils contain a high amount of phosphorus reaching over 15 to 150 times the needs of plants (Craaq, 2008), only bioavailable phosphorus is awardable to them and other living organisms. Measuring uniquely total phosphorus stock may not be therefore sufficient to evaluate the rate of phosphorus potentially releasable from sediments. All phosphorus forms are not able to be subjected to releasing (Ruban et al., 1996), and it appears important to know which part of the stock may be remobilizable. The measure of different phosphorus fractions in sediment sallows to understanding better the mobilizable phosphates, and then those equitable by algae (Rydin, 2000). An exceeded amount of bioavailable phosphorus in surface waters favorites growth ofaquatic vegetation such as phytoplankton and algae (Achat, 2009). This fact is bound to an increased alteration of watershed quality as well as a rapid modification in the fauna habitat.

Preliminary studies on the lagoon PortoNovo, notably those conducted by Chitou et al., (2011), revealed that this lagoon stirs a high amount of phosphorus. Akogbéto (2012) evaluated up to $3536 \mathrm{mg} / \mathrm{L}$ PT the phosphorus average rate present in the sediments and water column respectively, rendering the environment eutrophic. But those investigations lacked in identifying the different phosphorus fractions responsible of that augmentation as well as their bioavailability and on the other hand, the phosphorus release capacity in the water column which knowledge should ease establishment of any prevention actions. 
Well, in these kinds of hydrosystems, important interactions between sediments and water column exist and lead to a phosphorus release. These interactions are influenced by many factors such as water $\mathrm{pH}$, organic matter mineralization, etc. Oxygen presence and anoxia at the interface water-sediment for example modifies this release unidirectional water-sediment or sediment-water (Wetzel, 2001, Mortimer, 1941, Böstrom et al., 1988). That phosphorus release can be sometimes largely over external supplies (Sondergaard et al., 2003, Ryding and Burnberg, 1998) and cause a sudden increase of phosphorus rate, and as consequence the fish death.

This study enters the same logics insight to evaluate the release rate of phosphorus arising from lagoon sediments, and further to investigate this nutrient faction availability taking into account spatial and temporal variations in order to allow local authorities towards their consideration during any setting of eventual strategies on eutrophication reduction and on that lagoon restoration. Moreover, results from these studies shall broaden our knowledge with relevance to other or similar hydrosystems more or less connected with one another both at the national and sub-regional scales regarding the environmental phenomenon of interest.

\section{Materials and Methods}

\section{Study Sites}

With an area of $35 \mathrm{~km}^{2}$, Porto-Novo lagoon is located in South-eastern Benin between $6^{\circ} 25$ and $6^{\circ} 30 \mathrm{~N}$, and the meridians $2^{\circ} 30$ and $2^{\circ} 38$ E. On the one hand it is joined in the Northern part to the Ouémé river via a multitude of branches, from where it receives suit water and alleviated supplies in swelling water period, and on the other hand, the lagoon is connected to lake Nokoué in South-western through Totché channel and in the far Eastern via Atlantic ocean in Lagos where it receives saline water in dry season (Figure 1). PortoNovo lagoon undergoes influence of subequatorial climate with warm and wet characteristics of Southern Benin, with rainfall following two rainy seasons, a long (April-July) and a short (October-November) separated by two dry seasons from DecemberMarch and August-September (Adam and Boko, 1993). The lagoon investigated possesses a low depth preventing an installation of a veritable thermal stratification. Sediment and nutrient supply arises from the slope basin erosion and many anthropoid activities which elucidate the choice of the station S1 situated on the link rive at the village Djassin and more influenced by the above mentioned factors. In contrast, station $\mathrm{S} 2$ is located on the right rive in the village Wedji and less affected by watershed erosion. S2 was chosen for comparisons. Two other stations were also retained, Donoukpa (S3) on the right rive, and Tchakou (S4) on the link one to analyze the effects of Ouémé River (tributary of the lagoon) and the parameter behavior at the outflow to Nigeria. Table 1 shows characteristics of this studying and survey points.

The sampling survey was carried out in two steps; the first following the four seasons in the year $(\mathrm{GSP}=$ long rainy season; $\mathrm{PSS}=$ short dry season; $\mathrm{PSP}=$ short rainy season; GSS=long dry season) and at $10 \mathrm{~cm}$ depth to assess phosphorus release rate; and the second step consisted in taking probes at $5 \mathrm{~cm}$ depth to estimate the nutrient bioavailability.

\section{Probe Sampling and analysis methods}

\section{Water column}

$\mathrm{pH}$, potential redox (rH), temperature, Electrical conductivity (EC), Dissolved Oxygen (DO), organic and mineral matter in 
suspension (MES), transparency, TDS, depth and PT are physicochemical parameters associated to water column. Measurements of these parameters $(\mathrm{rH}$, temperature, $\mathrm{EC}, \mathrm{pH}$, DO, TDS, etc.) were carried out in situ in the morning between 8 am and $10 \mathrm{am}$. A WTW 3110 SET 1 portable $\mathrm{pH}$-meter was used to measure $\mathrm{pH}$ and $\mathrm{rH}$ with an accuracy of \pm 0.01. A Hach DR 800 colorimeter was used to measure turbidity and MES. Dissolved oxygen concentration was recorded with WTW TetraCon 325 Oximeter. WTW Cond 3210 was useful for measuring EC, TDS and temperature with accuracy of \pm 0.1 . A Secchi disc was necessary to measure the transparency and depth of the water.

Water chemical parameters such as PT were determined in the Laboratory and assayed by a Hach 2800 spectrophotometer according to AFNOR NFT 90-023.Chlorophyll a content was measured according to AFNOR NFT 90117 norm (1984).

Water taken at a depth of about $20 \mathrm{~cm}$ was stored in a $1.5 \mathrm{~L}$ bottle after carefully washing and rinsing it many times and washing it by the end with the water to be collected. These bottles were stored in a cooler and immediately conveyed to laboratory for chemical analysis. Two bottles were filled by station; the second being packed in black bag for determination of chlorophyll a content.

\section{Sediments}

Sediments were sampled in the same stations as previously for the physico-chemical profiles. A graduated cylindrical dispositive of $6 \mathrm{~cm}$ diameter, opened at the base and finely perforated at the second base, installed at mid-height of the cylinder, was plunged into the lagoon depths for a sequential probing. Sediment was registered in a black bag and maintained fresh in a cooler until expedition to laboratory where chemical parameters were determined. Analyses were performed on sieved sediments at $250 \mu \mathrm{m}$. Sediments were lyophilized using apparatus EYELA FDU-2110 at $3.5 \mathrm{~Pa}$ pressure and $25.5^{\circ} \mathrm{C}$ for 28 hours.

The first five $\mathrm{cm}$ layer stratum was used to fulfill phosphorus fractionation. This depth was chosen after preliminary analysis on three successive strata of five $\mathrm{cm}$ layer which informed that the phosphorus concentration drops according to depth. However, a stratum consisting in the 10 first $\mathrm{cm}$ was retained to estimate phosphorus release rate.

$\mathrm{pH}(\mathrm{KCl})$, organic matter content, alkalinity, exchangeable bases, cation exchange capacity (CEC), total phosphorus (PT) and its fractionation (labile $\mathrm{P}, \mathrm{Fe}-\mathrm{P}, \mathrm{Ca}-\mathrm{P}, \mathrm{Al}-\mathrm{P}$, Org$\mathrm{P})$ were physico-chemical parameters analyzed in investigated sediments :

NF X31-103 norm was used for sediment $\mathrm{pH}$ determination;

Organic matter content was obtained by calcinations at $550^{\circ} \mathrm{C}$ following AFNOR X31-102 (AFNOR, 1994) norm. Total organic carbon (COT) was then determines applying this norm.

Alkalinity was determined as carbonate percent reported to the sediment weight using the followed formula:

$\% \mathrm{CO}_{3}^{2-}=\frac{(20-X) \times 0.001 \times 60 \times 100}{100 \times 2 \times m}$

With $\mathrm{m}=$ sediment weight, and $\mathrm{X}=\mathrm{NaOH}$ volume by equivalence $(\mathrm{mL})$.

PT content estimation and its fractionation were achieved following similar methodology as in the water column using a spectrophotometer model Hach 2800 according to AFNOR NFT 90 - 023 norms. 
Different forms of phosphorus were extracted using $5 \mathrm{~g}$ dry sediment according to the protocol proposed by Hieltjes and Lijklema (1980) and Psenner (1984), modified by Rydin and Welch(1998). This methodology allowed the separation of labile phosphorus with $\mathrm{NH} 4 \mathrm{Cl}$ at $\mathrm{pH} 7, \quad \mathrm{Fe}-\mathrm{P}$ using $\mathrm{Na} 2 \mathrm{~S} 2 \mathrm{O} 4 / \mathrm{NaHCO} 3$, while $\mathrm{Ca}-\mathrm{P}$ was extracted in $\mathrm{HCl}$. Al-P and Org-P were separated in basic $(\mathrm{NaOH})$ medium for 16 hours extract digestion in the presence of potassium persulfate in acid solution, following the protocol of Gachter and Meyer (1992).

This extraction methodology is summarized in Figure 2 as presented below:

To study the short term scavenged phosphorus mobility in sediments, $\mathrm{pH}$ effect on phosphorus remobilization in oxic conditions was retained as criteria. To that end, bioavailable phosphorus will be determined after $\mathrm{pH}$ variation of the sediment percolation solution around the average $\mathrm{pH}$, e.g. at $\mathrm{pH} 5.7$ and 9. This study was conducted on another probe.

Other sequenced sediment probes were used for particle size analysis undertaken at the Laboratory of Geology, Mines and Environment (GME), University AbomeyCalavi.

Isovalue map was established using 3D Analyst of the ArcGIS (version 10.2) software allowing extrapolation of depth between points of given and known depth.

Determination of isovalue curves was possible through small equidistance (scale of $1 \mathrm{~m})$. Using the module ARCPY of the Spatial Analyst package of ArcToolbox, MNT file corrected by grid executable extension was applied to generate curves (isobaths) at different equidistance. Algorithm functioning under PYTHON language served as fundament for experimentations.

\section{Estimation of phosphorus release rate}

Release rate $\left(\mathrm{mg} \times \mathrm{m}^{-2} \times \mathrm{jour}^{-1}\right)$ was calculated by the means of regression equations established on the basis of Nürnberg regression equations (Nürnberg, 1988, 1996).

\section{Limiting conditions for the application of Nürnberg methodology}

Morphological characteristics: low mean depth proving the non-taking into account of oxygen profiles,

Oxycycline and thermocline are by the same depth,

Anoxic duration corresponds to the night duration [12 $\mathrm{h}$ in tropical areas according to Tailling (1957)],

Epilimnetic summery PT corresponds to that at the long dry season.

\section{Statistical analysis}

Data collected in the four stations retained for phosphorus load evaluation were compared among them and between the four annual seasons applying a one-way variance analysis (ANOVA1) for each parameter. Dunnett multiple range method applied to that oneway ANOVA permitted comparing $\mathrm{pH}$ means. All those analyses were achieved by MINITAB (2014) and JMP (SAS Institute, 2007) software.

Pearson correlation coefficient (r) and its significance were also estimated to verify existing relationship among parameters investigated, and to conclude on their interrelationships with respect to the environmental state of the lagoon. 


\section{Results and Discussion}

\section{Water column physico-chemical parameters}

Results on physico-chemical parameters of the water column are represented in Table 2.

Waters of the lagoon Porto-Novo are relatively less oxygenized. Water OD concentration shows a variation with relevance to season and station considered.

Site $\mathrm{S} 1$ registers highest average value $(2.00 \pm 0.53 \mathrm{mg} / \mathrm{L})$, while $\mathrm{S} 4$ presents the lower value $(1.24 \pm 0.38 \mathrm{mg} / \mathrm{L})$.

GSS shows the most oxygenized waters with a mean corresponding to $2.30 \pm 0.43 \mathrm{mg} / \mathrm{L}$ followed by GSP, PSS and with $2.28 \pm 0.5$ $\mathrm{mg} / \mathrm{L}, 1.20 \pm 0.26 \mathrm{mg} / \mathrm{L}$ and finally $0.90 \pm 0.20$ $\mathrm{mg} / \mathrm{L}$, respectively.

TDSs present the most elevated values for GSS and GSP with $2580.00 \pm 711.00 \mathrm{mg} / \mathrm{L}$ and $1444.8 \pm 355.75 \mathrm{mg} / \mathrm{L}$, respectively for a value around $120 \mathrm{mg} / \mathrm{L}$ in PSS and PSP. Site S3 registers the highest value $(1389 \pm 845 \mathrm{mg} / \mathrm{L})$ and S4 the lowest $(773 \pm 529 \mathrm{mg} / \mathrm{L})$.

Chlorophyll a has a relatively high mean value $(4.99 \pm 0.83)$. It stands at $5.54 \pm 1.76$ and $5.15 \pm 1.98$, respectively in PSS and PSP, whereas a value of $4.40 \pm 1.78$, the lowest during GSS. Site S2 shows the highest chlorophyll a content being $6.06 \pm 1.53$. The lowest rate $(3.70 \pm 1.65)$ is measured in Site S3.

Turbidity shows the highest value $(61.25 \pm 9.68 \mathrm{mg} / \mathrm{L})$ in PSP, and the lowest $(4.50 \pm 0.95 \mathrm{mg} / \mathrm{L})$ in GSS whereas PSS and GSP register $10.75 \pm 2.32 \mathrm{mg} / \mathrm{L}$ and $15.75 \pm 1.97 \mathrm{mg} / \mathrm{L}$, respectively. S3 offers the highest mean value $(30.25 \pm 19.12 \mathrm{mg} / \mathrm{L})$ followed by sites S2, S4 and S5 with mean values corresponding to $21.75 \pm 14.63 \mathrm{mg} / \mathrm{L}$, $20.75 \pm 9.68 \mathrm{mg} / \mathrm{L}$ and $19.50 \pm 8.72 \mathrm{mg} / \mathrm{L}$, respectively.

Waters of lagoon Porto-Novo are more transparent in PSP and GSS with average values of $128.50 \pm 35.06 \mathrm{~cm}$ and $127.25 \pm 33.80$ $\mathrm{cm}$, respectively. PSS is the less transparent with a mean transparency equalling to $72.25 \pm 12.96 \mathrm{~cm}$. In $\mathrm{S} 2$ and $\mathrm{S} 3$, the highest transparencies were recorded with values corresponding to $126.75 \pm 33.75 \mathrm{~cm}$ and $112.50 \pm 42.78 \mathrm{~cm}$. S1 presents the lowest transparency $(80.75 \pm 5.50 \mathrm{~cm})$.

Values recorded for temperature show certain homogeneity from a season to another. Highest values are registered during GSS and PSP, with respectively $32.82 \pm 0.20^{\circ} \mathrm{C}$ and $30.60 \pm 0.48^{\circ} \mathrm{C}$. Lowest values are obtained in GSP and PSS oscillating around $27^{\circ} \mathrm{C}$. No significant variation is observed from a site to another.

$\mathrm{rH}$ is highest $(24.78 \pm 5.38 \mathrm{mV})$ in PSS, and lowest $(0.58 \pm 4.77 \mathrm{mV})$ in PSP. These values are indicating oxic conditions at the sediment surface in the whole sites by these periods. During GSS and GSP, anoxic conditions are observed with values of $15.78 \pm 4.80 \mathrm{mV}$ and $11.95 \pm 6.06 \mathrm{mV}$, respectively. Station S3 registers the highest mean value ($11.78 \pm 10.50 \mathrm{mV})$, while $\mathrm{S} 4$ delivers the lowest $(0.33 \pm 6.90 \mathrm{mV})$.

GSS registers highest average value for water PT $(5.03 \pm 0.40 \mathrm{mg} / \mathrm{L})$ followed in PSS and PSP with average mean of $2.14 \pm 0.44$ and $1.86 \pm 0.48 \mathrm{mg} / \mathrm{L}$. The lowest concentration $(0.97 \pm 0.34)$ is dosed in GSP, and seems corresponding to dilution effect due to rainy water. The highest value $(3.01 \pm 0.48 \mathrm{mg} / \mathrm{L})$ has been recorded in site $\mathrm{S} 1$ witnessing a continental origin for this nutrient. All other stations present PT content comprised between $2.77 \pm 1.00$ and $2.07 \pm 0.84 \mathrm{mg} / \mathrm{L}$. 


\section{Sediment physico-chemical characteristics}

\section{Sediments}

Hydromorphic soils mildly organic, humic with gley, not or little saline and undifferentiated, located on lagoon alluvial and alluvio-colluvial fluvial material, are observed in lagoon Porto-Novo (Alassane, 2004). These are extremely heterogenic soils having as common character the presence of a permanent water sheet at low depth which provokes the formation of an organic matter horizon badly or very little decomposed.

In average, soil texture is organic more or less rich in silt by their surface, and sandy-loam at depth. In some stations, texture is clearly loamy. Results out of particle size surveys are presented in Table 3.

\section{pH (KCl) and pH (eau)}

Figure 3 is showing that water $\mathrm{pH}$ and sediment $\mathrm{pH}(\mathrm{KCl})$ are acid and relatively low from a season to another. From $6.41 \pm 0.07$ in PSS, $\mathrm{pH}$ increases to $6.96 \pm 0.08$ and $6.91 \pm 0.10$, respectively in GSS and GSP. Station S3 presents the highest $\mathrm{pH}$ $(6.91 \pm 0.17)$ and the lowest is observed in $\mathrm{S} 1$ (6.63 \pm 0.14$)$. $\mathrm{pH} \quad(\mathrm{KCl})$ mean value is $6.61 \pm 0.24$. S3 and S4 present respectively $7.09 \pm 0.51$ and $6.92 \pm 0.58$ as $\mathrm{pH}(\mathrm{KCl})$. The lowest value is registered at site S2 (5.57 \pm 0.25$). \quad \mathrm{pH}($ water) and sediment $\mathrm{pH}(\mathrm{KCl})$ mean value comparison by Dunnett method applied to one-way ANOVA (factor station) showed that mean values considered by pair are not significantly different from $\mathrm{pH}$ (water) and $\mathrm{pH}(\mathrm{KCl})=7$ (water $\mathrm{pH}$ in $\mathrm{S} 3=7.21$ during $\mathrm{GSS}$, and sediment $\mathrm{pH}(\mathrm{KCl})$ in S3 equals 8.10 at GSP) by $95 \%$ confidence, given that variance comparisons revealed always negative values (absolute value of variance difference-LSD) whatever the station of interest $(\mathrm{p}>0.05)$.

\section{Alkalinity and organic matters}

Figure 4 is presenting temporal variation of carbonates, organic matter and total carbon content from a season to another.

Carbonates rate at $\mathrm{S} 1$ is the lowest $(1.02 \pm 0.11 \%)$ while $\mathrm{S} 4$ shows the highest value $(11.90 \pm 1.60 \%)$. PSP registers the lowest content in all seasons $(2.98 \pm 1.42 \%)$. It varies between $(4.80 \pm 3.26)$ and $(4.48 \pm 2.92 \%)$ for GSP, GSS and PSS. MO shows a mean value of $8.56 \pm 2.33$. S4 is the site with highest MO concentration $(23.83 \pm 1.46 \%)$. Low values $(2.98 \pm 0.51$ and $2.19 \pm 0.45)$ are recorded respectively in S3 and S1. GSP and PSP indicate highest MO showing a variation ranging from $9.18 \pm 4.74$ to $9.22 \pm 6.27$. GSS and PSS register $7.83 \pm 5.03$ and $7.67 \pm 5.05 \%$ $\mathrm{MO}$, respectively.

COT content ranges from $3.80 \pm 1.54 \%$ to $3.06 \pm 1.53$ in different seasons. It varies from $9.52 \pm 0.63 \%$ (maximal concentration) in S4 in contrast to S1 with the lowest COT $(0.87 \pm 0.18)$

\section{Phosphorus composition and its fractionation}

According to Figure 5, dry sediment PT launches a mean value of $1561 \pm 261 \mu \mathrm{g} / \mathrm{g}$. It corresponds to $1983 \pm 973 \mu \mathrm{g} / \mathrm{g}$ (S4) and $1264 \pm 466 \mu \mathrm{g} / \mathrm{g}(\mathrm{S} 3)$. PT oscillates between $1659 \pm 614 \mu \mathrm{g} / \mathrm{g}$ and $1337 \pm 307 \mu \mathrm{g} / \mathrm{g}$ in $\mathrm{S} 1$ and S2. Mean PT concentration registers the highest value during GSS with 2783.3 \pm 742.7 $\mu \mathrm{g} / \mathrm{g}$ followed by values in PSP $(1970.3 \pm 241.05 \quad \mu \mathrm{g} / \mathrm{g})$. Lowest PT concentrations $(445.3 \pm 12.05 \mu \mathrm{g} / \mathrm{g})$ are noted during PSS.

Total phosphorus stock evaluation remains a very good approach for a better understanding of sediment contamination degree and extent. But generally, such evaluation opens doors to 
little information on mobility of the concerned element in the sediments. Fractioning allows then to highlight the different forms presented by phosphorus in sediments arisen from the sampling points. Among those forms, dissolved labile mineral phosphorus $\left(\mathrm{PO}_{4}{ }^{3-}\right)$ in interstitial waters is directly equitable by algae. Fraction bound to iron $(\mathrm{P}-\mathrm{Fe})$ represents the most available fraction.

Figures 6-9 illustrate spatial repartition of the different phosphorus forms observed: labile form, P-Fe, P-Ca, P-Al and P-Org accompanied by P-resid.

At S1, P-Org and P-Ca represent the main fractions with $810.80 \pm 151.25 \mu \mathrm{g} / \mathrm{g}$ and $103.15 \pm 42.77$ equalling to $54.41 \%$ and $6.92 \%$ PT, respectively. This rate is $55.62 \%$ and $1.63 \%$ in $\mathrm{S} 2,66.36 \%$ and $1.83 \%$ at $\mathrm{S} 3$, and $55.13 \%, 5.90 \%$ at $\mathrm{S} 4$.

P-labile is the less represented fraction ranging from $14.75 \pm 2.70 \mu \mathrm{g} / \mathrm{g}$ (corresponding to $0.98 \% \mathrm{PT}$ ) at $\mathrm{S} 1$ to $0.75 \%, 0.44 \%$ and $2.07 \%$ for S2, S3 and S4, respectively. Remaining fractions, $\mathrm{P}-\mathrm{Al}$ and $\mathrm{P}-\mathrm{Fe}$ are 3.44 and $1.44 \%$ in $\mathrm{S} 1$, while they are represented by $1.43,0.68,0.88,0.36,2.24$ and $0.72 \%$ at S2, S3 and S4, respectively.

Highest P-Org concentration is observed in GSS across February, and corresponds to $2035.40 \pm 311.20 \mu \mathrm{g} / \mathrm{g}$, whereas the lowest is noted for PSS in September. In the later season, P-Al is rather more concentrated in sediments $(48.73 \pm 10.95 \mu \mathrm{g} / \mathrm{g})$. P-Al is lower during GSS $(17.95 \pm 9.24 \mu \mathrm{g} / \mathrm{g})$. Similar variations are observed for all other phosphorus fractions. Thus, P-Fe and P-labile represent $17.23 \pm 10.45 \mu \mathrm{g} / \mathrm{g}$ and $40.89 \pm 2.50$ $\mu \mathrm{g} / \mathrm{g}$ in GSS, respectively. Their lower values are $11.41 \pm 1.02 \mu \mathrm{g} / \mathrm{g}$ and $8.92 \pm 0.69 \mu \mathrm{g} / \mathrm{g}$, respectively during PSS and GSP. Sediment $\mathrm{P}-\mathrm{Ca}$ maximal content is around
$132.55 \pm 40.60 \mu \mathrm{g} / \mathrm{g}$ in PSP and $2.56 \pm 1.30$ $\mu \mathrm{g} / \mathrm{g}$ - the lowest value - during GSS.

Residual organic phosphate (P-resid) in the lagoon Porto-Novo is higher during GSS $(1299.20 \pm 275.20 \mu \mathrm{g} / \mathrm{g})$ and lower $(274.4$ $\pm 274.4 \mu \mathrm{g} / \mathrm{g}$ ) in PSS. The highest P-resid mean is recorded in $\mathrm{S} 3(758.10 \pm 273.25 \mu \mathrm{g} / \mathrm{g})$, while its value is the lowest in S1 $(489.70 \pm 145.10 \mu \mathrm{g} / \mathrm{g}) . \quad \mathrm{S} 2$ and $\mathrm{S} 4$ show $603.9 \pm 442.20 \mu \mathrm{g} / \mathrm{g}$ and $625.00 \pm 306.80 \mu \mathrm{g} / \mathrm{g}$ P-resid, respectively.

$\mathrm{Ca}^{2+}, \mathrm{K}^{+}, \mathrm{Mg}^{2+}$ and $\mathrm{Na}^{+}$concentrations as well as cationic exchange capacity are obtained at GSS (February) and within the four sampling sites under investigation (Table 4).

Highest values for those ions are noted from sediments of S1 followed by S3 and S4. The lowest values are observed at site S2. That increase of ion concentration at S1 can be explained by the high pollution recorded at this station. Hence, S1 is where many economical activities run, but also it receives waters arising from Zounvi, the main channel to drain off wastewaters from the town PortoNovo (Table 4).

Cationic exchange capacity (CEC) represents the maximal amount of ions able to be exchanged on a solid in presence of an ion excess in solution. It varies among 14 meq/100g (S3) during PSP and $32 \mathrm{meq} / 100 \mathrm{~g}$ (S1) at the same season with a mean value corresponding to $24.25 \mathrm{meq} / 100 \mathrm{~g}$ the most elevated at site S1 (Table 4).

\section{Short-term mobility of phosphorus in sediments}

Phosphorus release by sediments is affected by external factors such as dissolved oxygen content, $\mathrm{pH}$ in water column as well as climatic factors including water column stirring through the wind (Reddy et al., 2008). 
Table.1 Survey site geographical coordinates

\begin{tabular}{|l|l|l|l|}
\hline Sites & Codes & Coordinates & Reasons on the Choice \\
\hline Djassin & S1 & $\begin{array}{l}06^{\circ} 28^{\prime} 14.2^{\prime} \\
002^{\circ} 36^{\prime} 0.16^{\prime}\end{array}$ & $\begin{array}{l}\text { Household muck discharge, mechanically water hyacinth destruction, good } \\
\text { and sand traffics by humans. }\end{array}$ \\
\hline Wedji & S2 & $\begin{array}{l}06^{\circ} 27^{\prime} 42.6^{\prime} \\
002^{\circ} 34^{\prime} 39.0^{\prime \prime}\end{array}$ & concentration zone of 'acadjas' (Fishing technique) \\
\hline Donoukpa & S3 & $\begin{array}{l}06^{\circ} 28^{\prime} 15.3^{\prime \prime} \\
002^{\circ} 35^{\prime} 02.0^{\prime \prime}\end{array}$ & Entry of Ouémé river, tributary of that lagoon \\
\hline Tchakou & S4 & $\begin{array}{l}06^{\circ} 27^{\prime} 34.6^{\prime \prime} \\
002^{\circ} 42^{\prime} 62.9^{\prime}\end{array}$ & Exit of the lagoon. \\
\hline
\end{tabular}

Table.2 Mean and standard deviation of physico-chemical parameters in relation to seasons

\begin{tabular}{|l|l|l|l|l|l|l|l|}
\hline Parameters & GSP & PSS & PSP & GSS & Min & $\max$ & Moy \\
\hline Temp & $27.10 \pm 0.16$ & $27.62 \pm 0.07$ & $30.60 \pm 0.48$ & $32.82 \pm 0.20$ & 33.10 & 26.90 & $29.53 \pm 0.61$ \\
\hline OD & $2.28 \pm 0.5$ & $1.20 \pm 0.26$ & $0.90 \pm 0.20$ & $2.30 \pm 0.43$ & 3.54 & 0.53 & $1.67 \pm 0.23$ \\
\hline TDS & $1444.8 \pm 355.75$ & $120.7 \pm 14.05$ & $120.00 \pm 10.00$ & $2580.00 \pm 711.00$ & 3660 & 93.5 & $1066.00 \pm 319.00$ \\
\hline Turb & $15.75 \pm 1.97$ & $10.75 \pm 2.32$ & $61.25 \pm 9.68$ & $4.50 \pm 0.95$ & 87.00 & 2.00 & $23.06 \pm 6.22$ \\
\hline Predox & $-11.95 \pm 6.06$ & $24.78 \pm 5.38$ & $0.58 \pm 4.77$ & $-15.78 \pm 4.80$ & 39.80 & -30.10 & $-0.59 \pm 4.72$ \\
\hline Transp & $78.00 \pm 5.83$ & $72.25 \pm 12.96$ & $128.50 \pm 35.06$ & $127.25 \pm 33.80$ & 230.00 & 38.00 & $101.5 \pm 13.2$ \\
\hline Chl a & $4.88 \pm 1.84$ & $5.54 \pm 1.76$ & $5.15 \pm 1.98$ & $4.40 \pm 1.78$ & 9.52 & 1.22 & $4.99 \pm 0.83$ \\
\hline
\end{tabular}

Table.3 Particle size composition and substratum nature at different sites in lagoon Porto-Novo

\begin{tabular}{|c|c|c|c|c|c|}
\hline \multirow[t]{2}{*}{ STATIONS } & \multirow[t]{2}{*}{ CODES } & \multirow[t]{2}{*}{ COULOUR } & \multicolumn{2}{|c|}{ PARTICLE SIZE } & \multirow{2}{*}{$\begin{array}{l}\text { CLASSIFICATION } \\
\text { (according to Intès et } \\
\text { Loeuff-1986) }\end{array}$} \\
\hline & & & (\%) S & $(\%) \mathrm{A}+\mathrm{L}$ & \\
\hline \multirow{3}{*}{ Djassin } & $\mathrm{S}_{1} \mathrm{~A}$ & Black & 63.18 & 35.68 & Sandy-loamy \\
\hline & $\mathrm{S}_{1} \mathrm{~B}$ & Greyish & 73.94 & 25.16 & Sandy-loamy \\
\hline & $\mathrm{S}_{1} \mathrm{C}$ & Greyish & 74.00 & 25.24 & Sandy-loamy \\
\hline \multirow{3}{*}{ Wedji } & $\mathrm{S}_{2} \mathrm{~A}$ & Greyish & 21.37 & 78.29 & Loamy-sandy \\
\hline & $\mathrm{S}_{2} \mathrm{~B}$ & Greyish & 46.95 & 52.29 & Loamy-sandy \\
\hline & $\mathrm{S}_{2} \mathrm{C}$ & Grey & 45.43 & 64.18 & Loamy-sandy \\
\hline \multirow{3}{*}{ Donoukpa } & $\mathrm{S}_{3} \mathrm{~A}$ & Black & 30.66 & 69.10 & Loamy-sandy \\
\hline & $\mathrm{S}_{3} \mathrm{~B}$ & Grey & 23.83 & 75.15 & Loamy-sandy \\
\hline & $\mathrm{S}_{3} \mathrm{C}$ & Grey & 50.29 & 48.53 & Sandy-loamy \\
\hline \multirow{3}{*}{ Tchakou } & $\mathrm{S}_{4} \mathrm{~A}$ & Greyish & 18.84 & 80.62 & Silty \\
\hline & $\mathrm{S}_{4} \mathrm{~B}$ & Greyish & 25.17 & 74.22 & Loamy-sandy \\
\hline & $\mathrm{S}_{4} \mathrm{C}$ & Greyish & 47.71 & 51.26 & Loamy-sandy \\
\hline
\end{tabular}

Legend: $\mathrm{S}$ = sand: elements with diameter among $63 \mu \mathrm{m}$ and $02 \mathrm{~mm}$; A = loam: elements with diameter inferior to 4 $\mu \mathrm{m} ; \mathrm{L}=$ silt: elements with diameter among $63 \mu \mathrm{m}$ and $4 \mu \mathrm{m}$.

Table.4 Evolution of exchangeable cations and CEC means at four sites investigated in the lagoon Porto-Novo

\begin{tabular}{|l|l|l|l|l|l|}
\hline SITES & $\mathrm{Ca}^{2+}(\mathrm{meq} / 100 \mathrm{~g})$ & $\mathrm{K}^{+}(\mathrm{meq} / 100 \mathrm{~g})$ & $\mathrm{Mg}^{2+}(\mathrm{meq} / 100 \mathrm{~g})$ & $\mathrm{Na}^{+}(\mathrm{meq} / 100 \mathrm{~g})$ & $\mathrm{CEC}(\mathrm{meq} / 100 \mathrm{~g})$ \\
\hline S1 & 6.85 & 0.32 & 6.95 & 1.95 & 24.25 \\
\hline S2 & 2.7 & 0.13 & 2.47 & 0.45 & 20.25 \\
\hline S3 & 3.32 & 0.19 & 3.65 & 0.75 & 19.5 \\
\hline S4 & 3.72 & 0.21 & 4.92 & 1.8 & 16.5 \\
\hline
\end{tabular}


Table.5 Correlation coefficients between some parameters with p-values

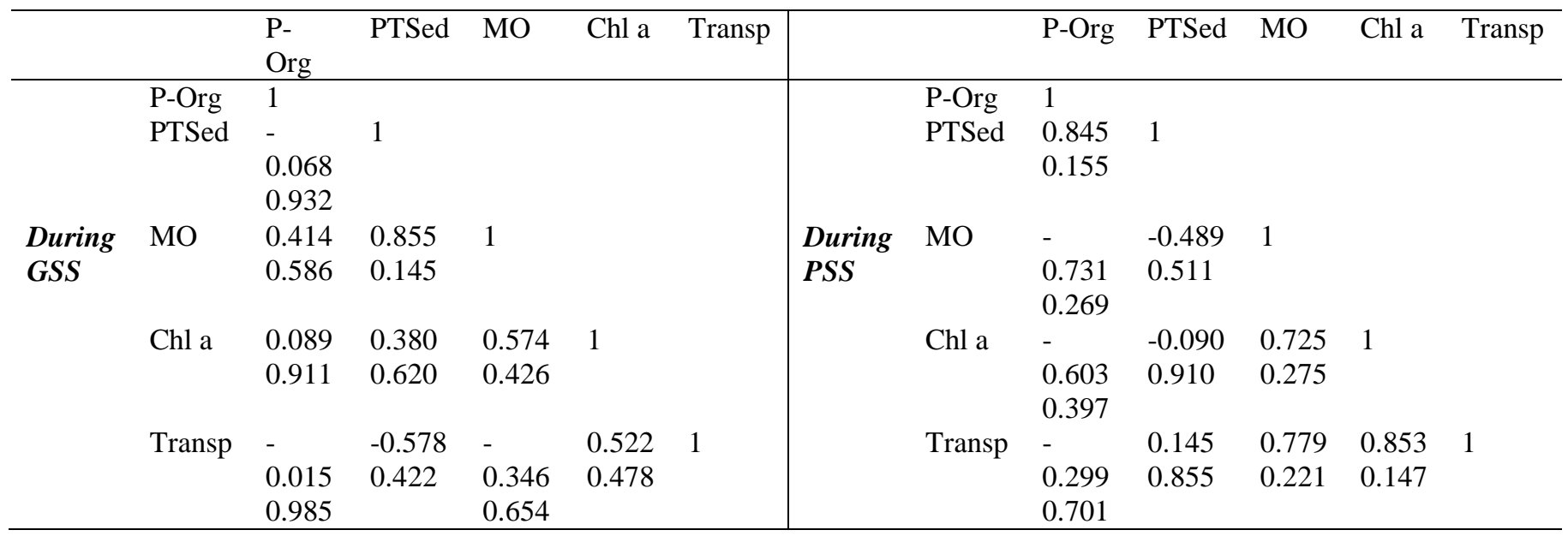

Fig.1 Localization of lagoon Porto-Novo in the lagoon complex of South-eastern Benin

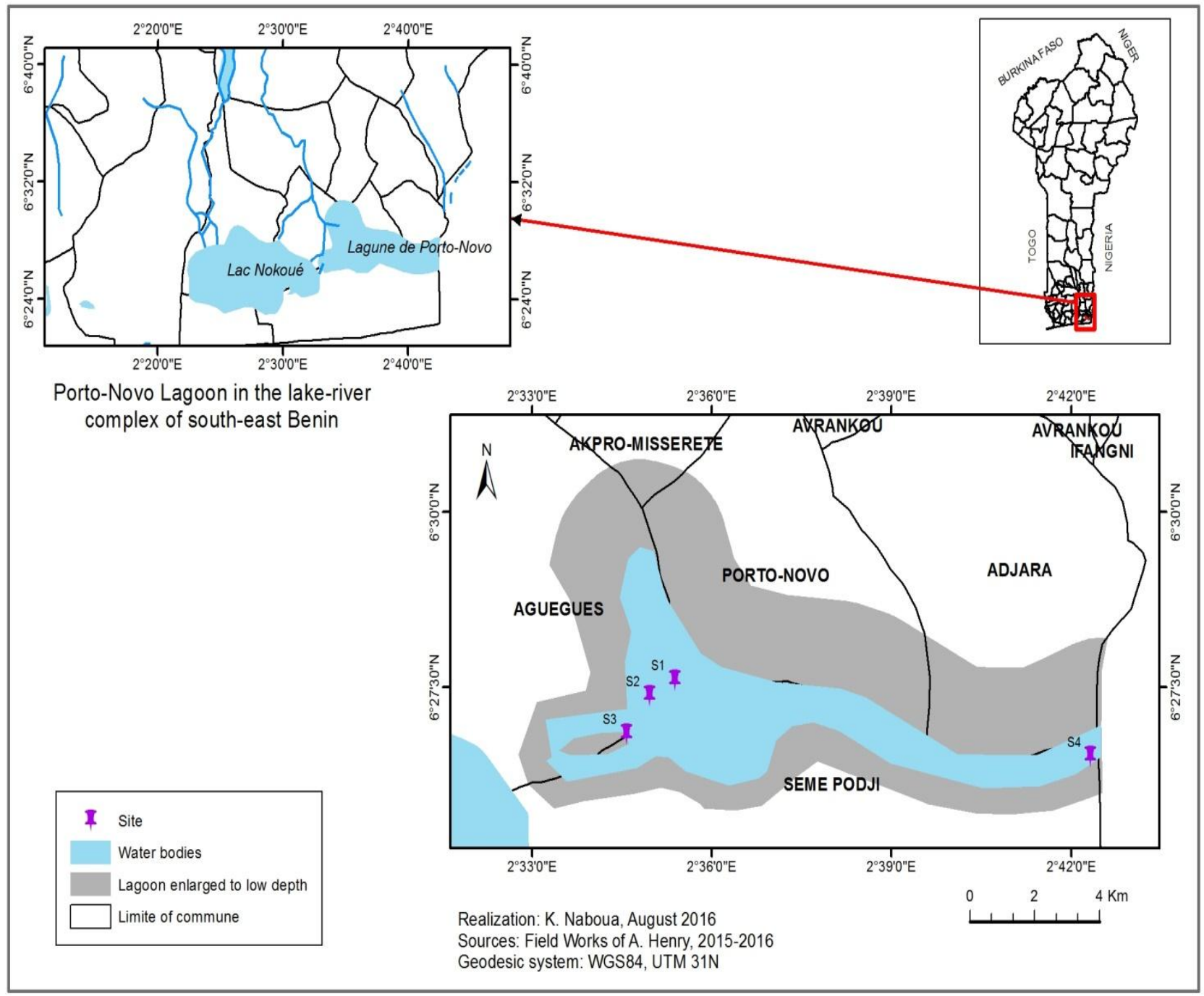


Fig.2 Sequential extraction scheme of phosphorus according to Rydin and Welch (1998)

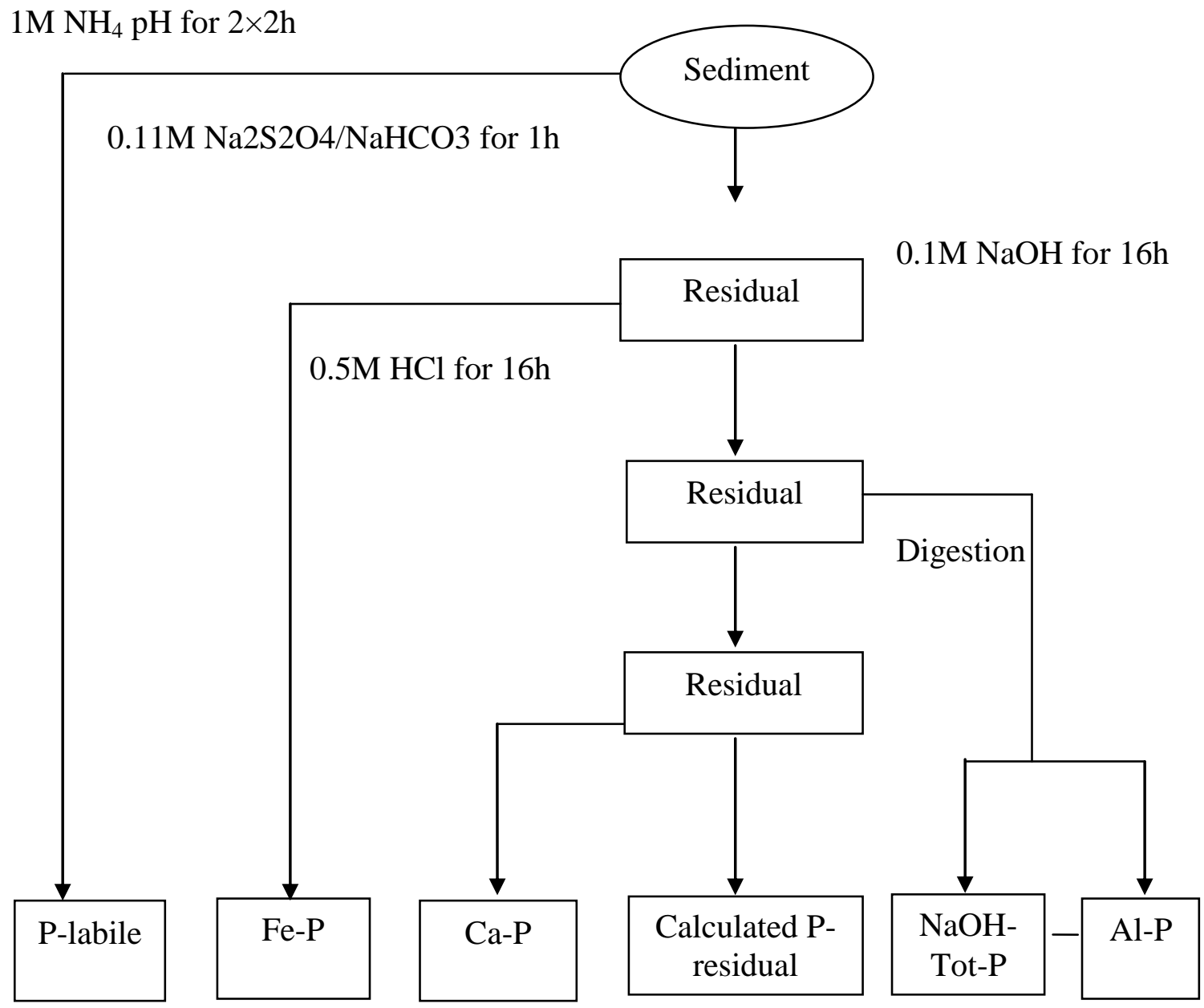

Org/Bact-P

Fig.3 Variation of sediment $\mathrm{pH}$ (water) and $\mathrm{pH}(\mathrm{KCl})$ reported to seasons and sampling sites

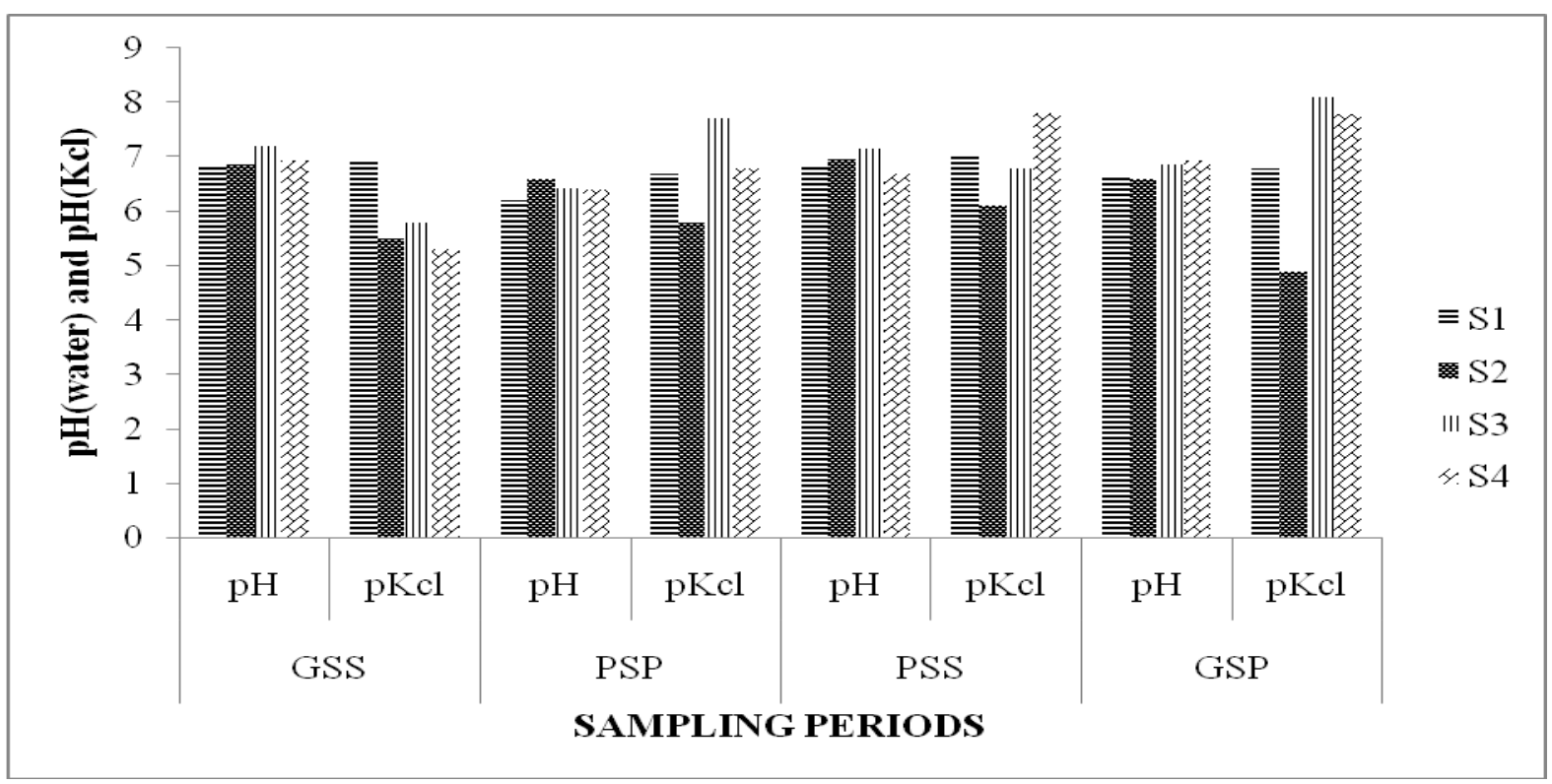


Fig.4 Evolution of carbonate and organic matter rate in all seasons in the year

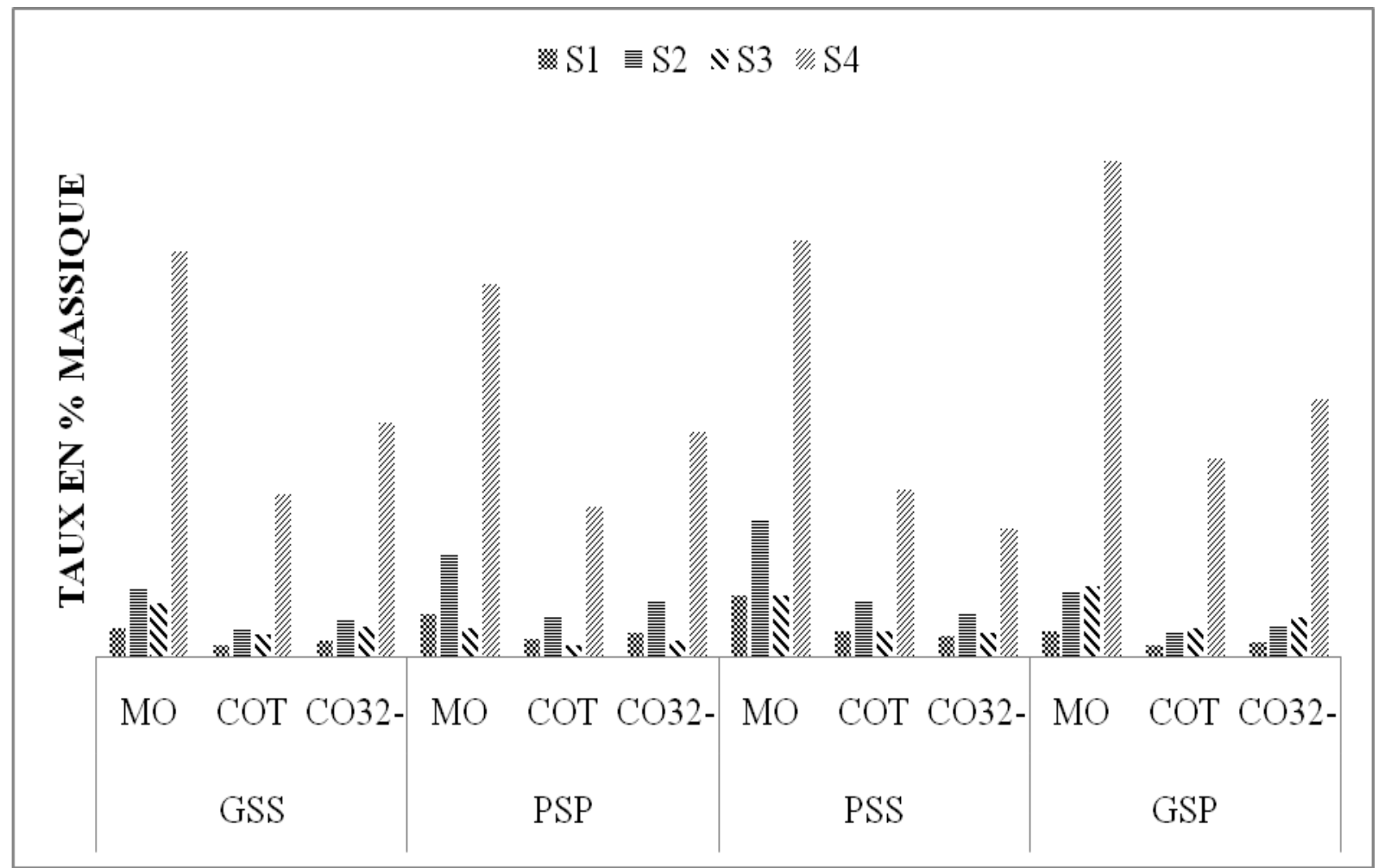

Fig.5 Evolution of sediment PT at $10 \mathrm{~cm}$ depth at the four sites studied in the lagoon Porto-Novo

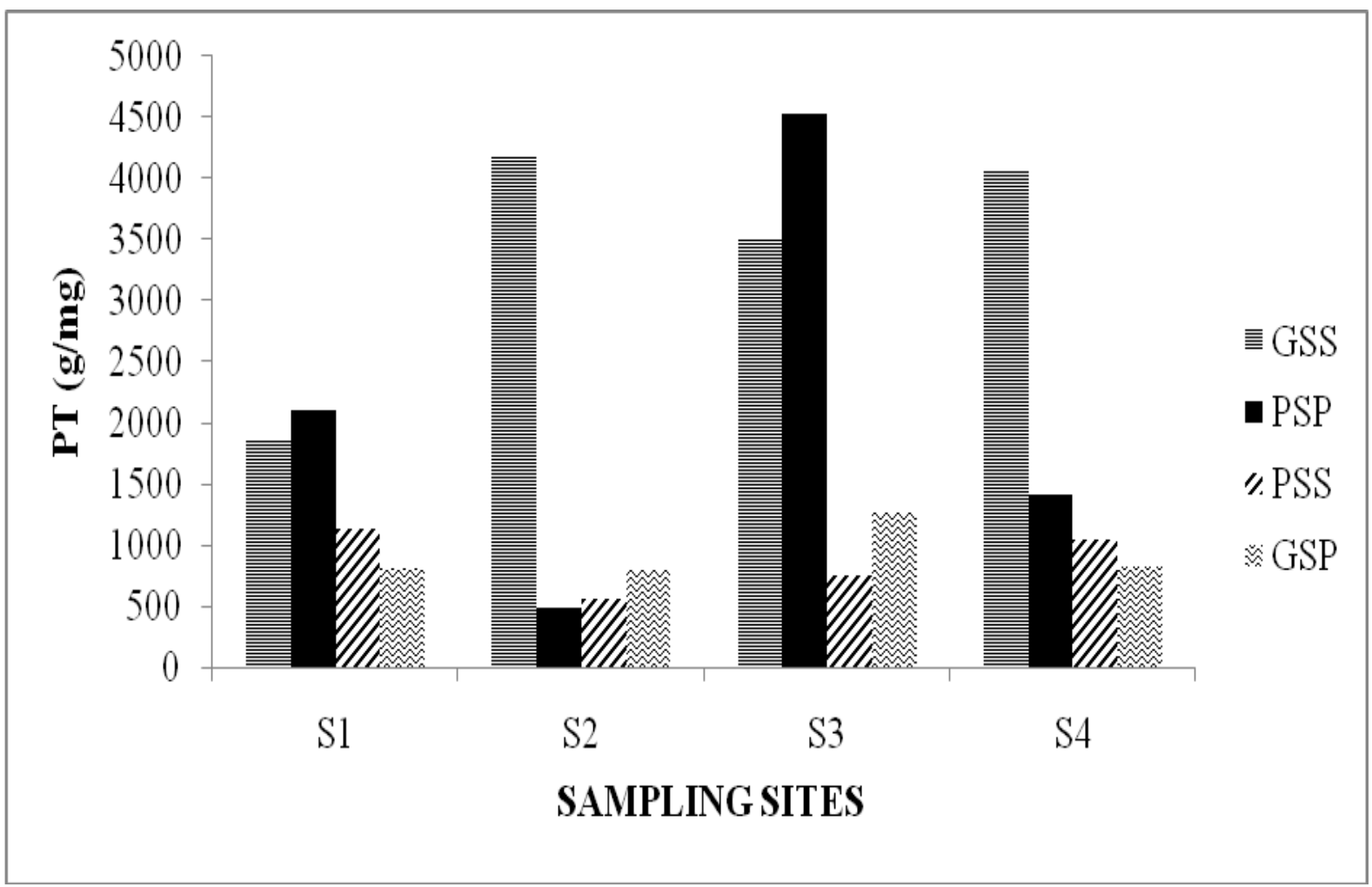


Fig.6 Phosphorus fractionation at site S1

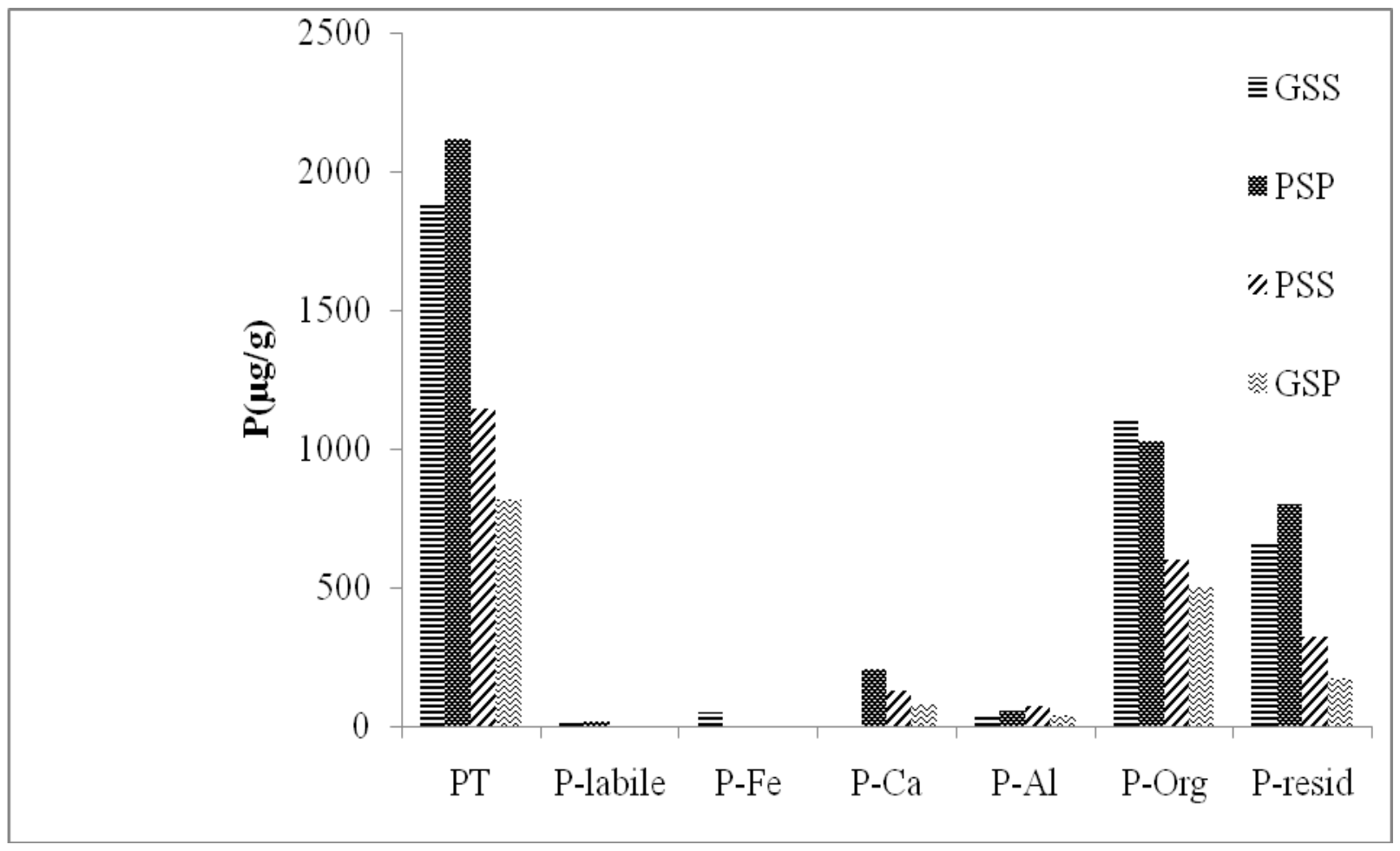

Fig.7 Phosphorus fractionation at site S2

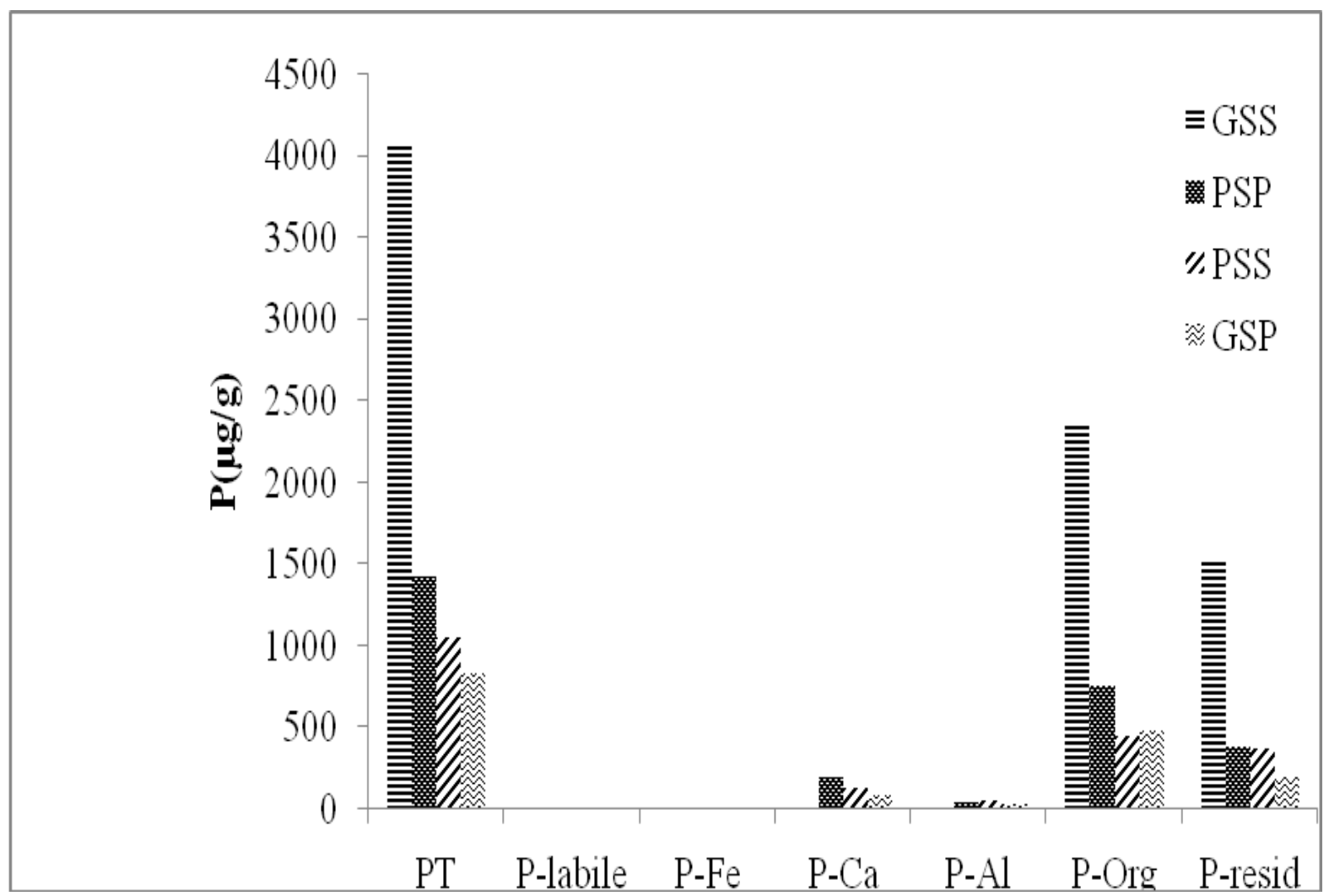


Fig.8 Phosphorus fractionation at site S3

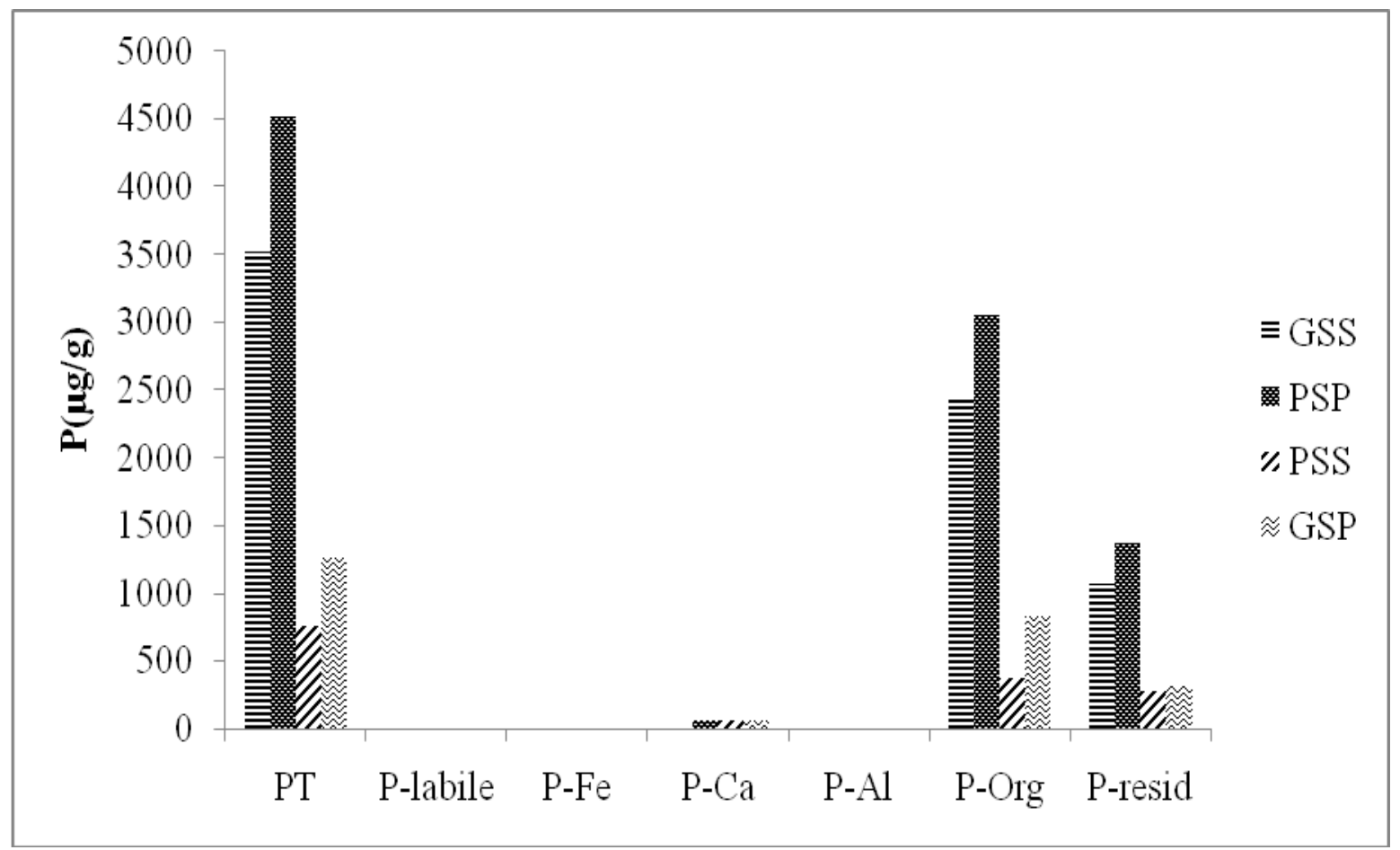

Fig.9 Phosphorus fractionation at site S4

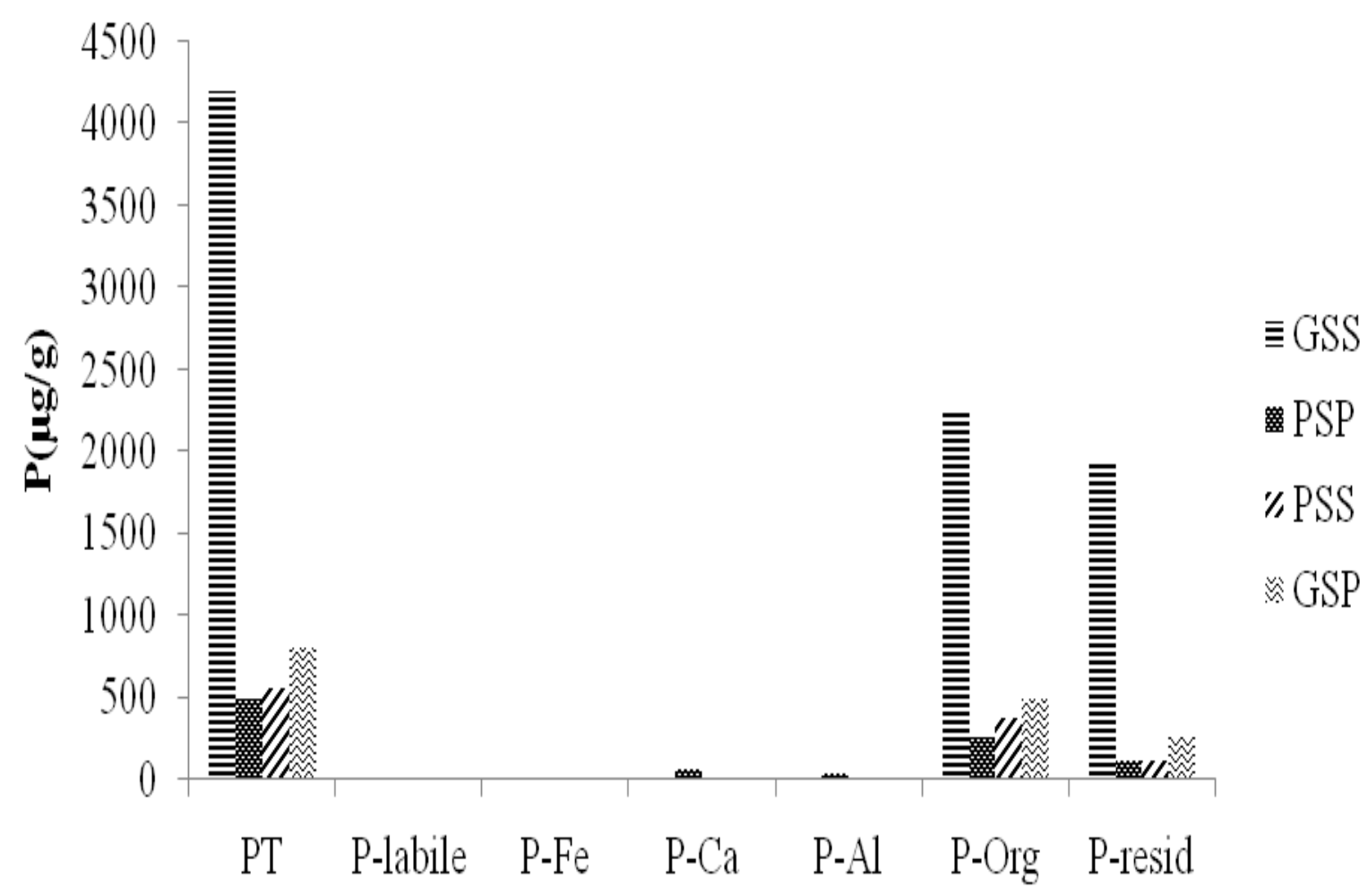


Fig.10 Variation of phosphorus fraction content at different $\mathrm{pH}$

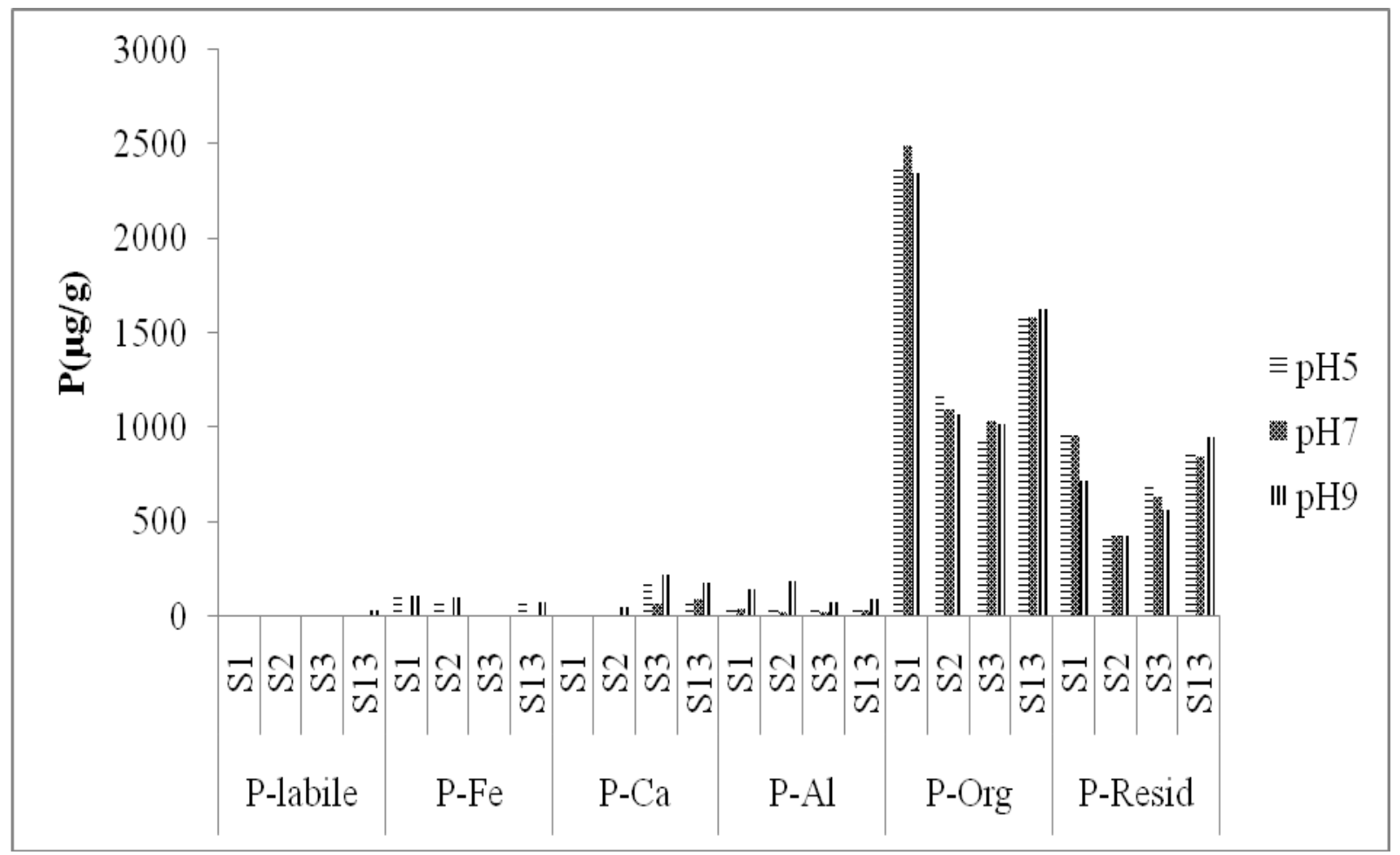

Fig.11 PT variation according to TL

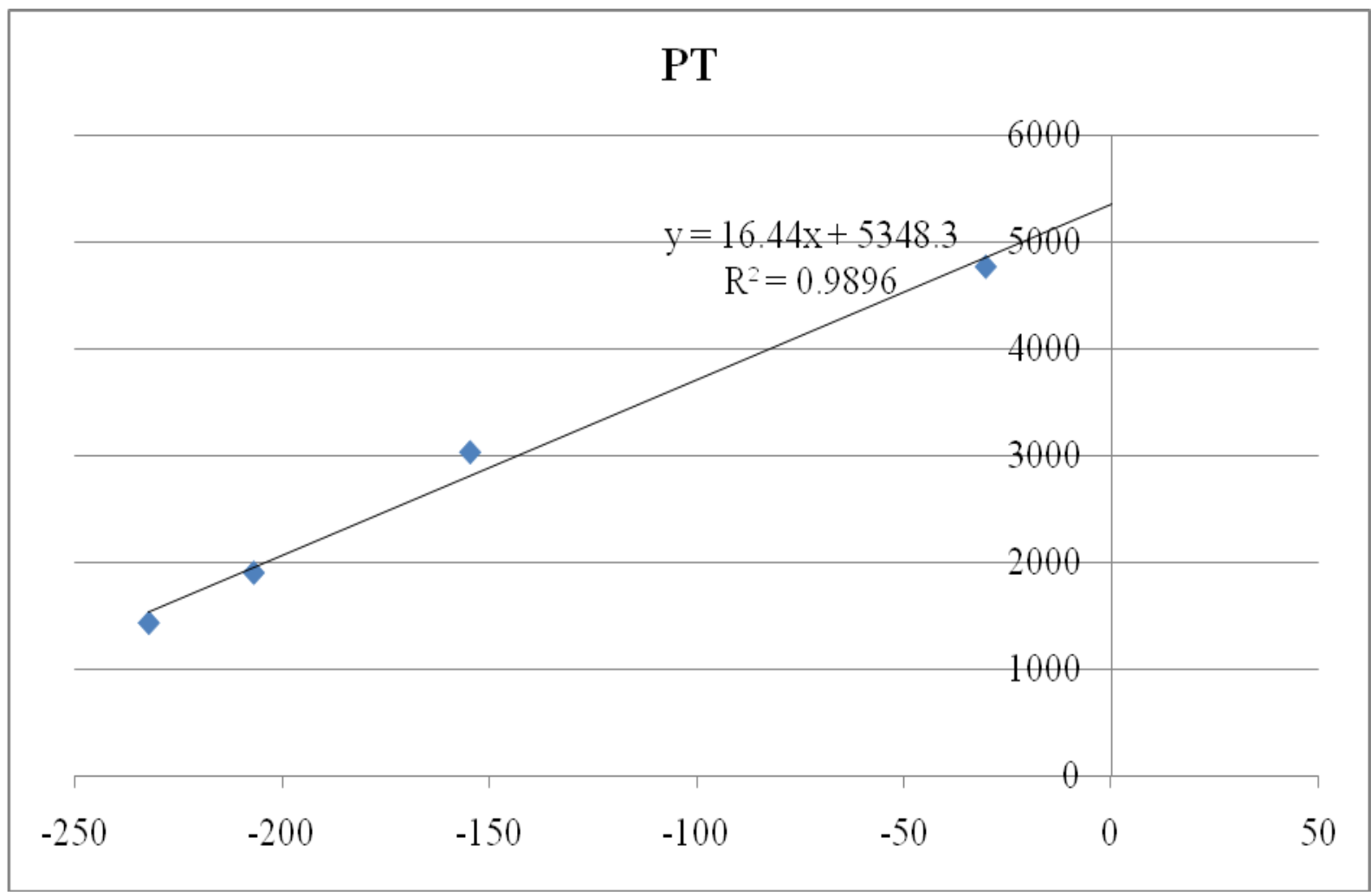


Fig.12 ISO value curves

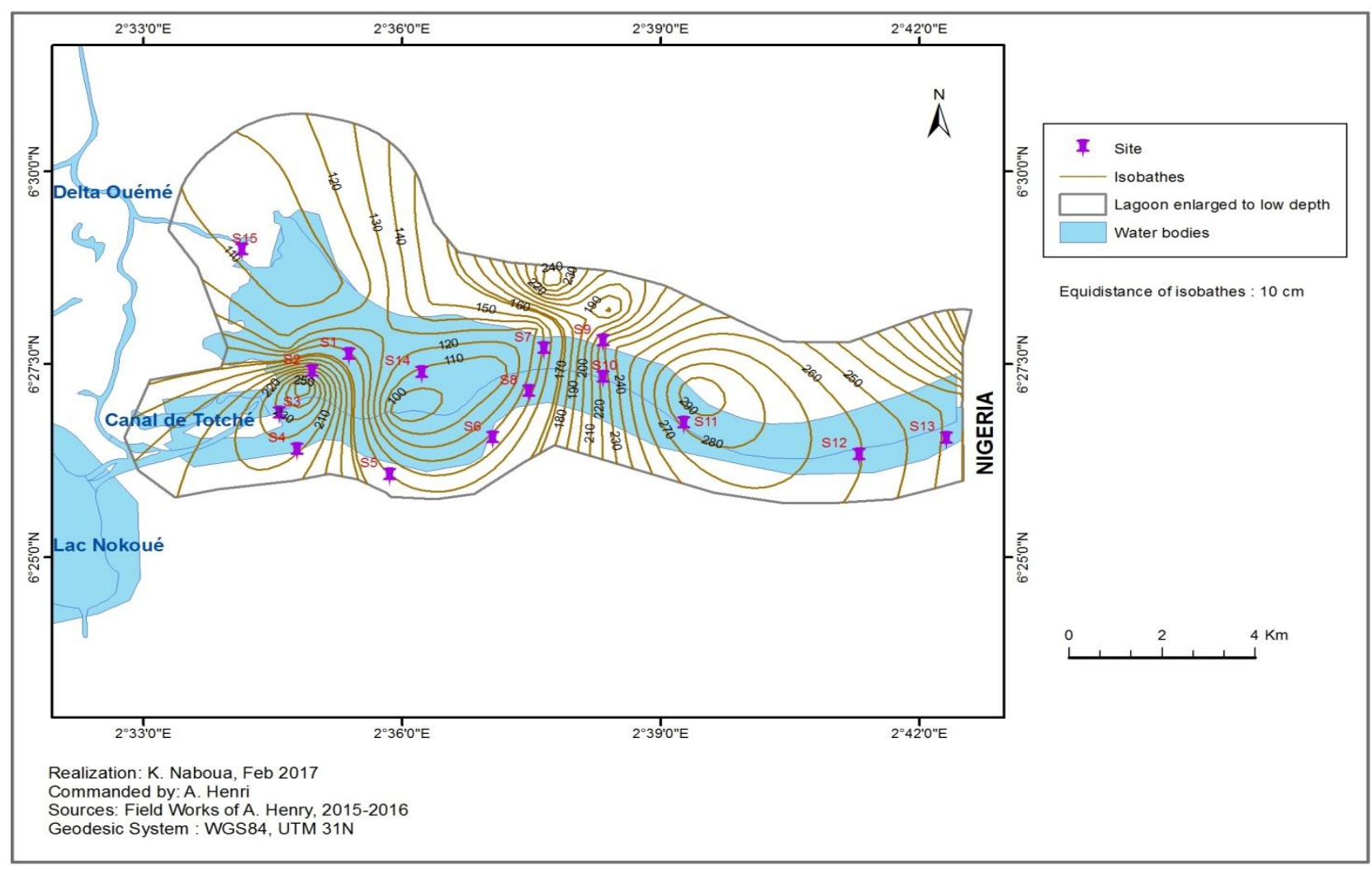

Water column $\mathrm{pH}$ and sediment $\mathrm{pH}(\mathrm{KCl})$ in all sampling sites and the whole experimental period present no significant mean compared to $7 . \mathrm{pH} 7$ is used as reference one. $\mathrm{pH}$ variation around 5 and 9 under oxic conditions gives some results on phosphorus fractions as shown in Figure 10.

P-labile, $\mathrm{P}-\mathrm{Fe}$ and $\mathrm{P}-\mathrm{Al}$ contents at $\mathrm{pH} 5$ and 9 are higher in all sites if compared to the registered values at $\mathrm{pH} 7$ considered as environmental $\mathrm{pH}$ by the time of experimentation. $\mathrm{P}-\mathrm{Ca}$ indicates the same trends apart from site $\mathrm{S} 1$ where its concentration at $\mathrm{pH} 5$ and 9 is inferior to that observed at $\mathrm{pH} 7$. With respect to P-Org, concentration at $\mathrm{pH} 5$ and 9 is inferior to that observed at $\mathrm{pH} 7$ at $\mathrm{S} 1$ and S3. It is rather higher at S4. P-Org at $\mathrm{S} 2$ is higher at $\mathrm{pH} 5$ compared to $\mathrm{pH} 7$ and lower at $\mathrm{pH} 9$ thanat $\mathrm{pH} 7$ being the reference.
PH decrease or increase favourites so the phosphorus fractionation release.

This is conformed to the observation of Böstrom et al., (1988) on lake sediment, and these variations of $\mathrm{pH}$ should emphasize eutrophication phenomenon.

\section{Phosphorus release rate}

Nürnberg regression equations (Nürnberg, 1988, 1996) are shown as below:

$T L=4.78+2.75[P T]-0.177[L O I]$

At $10 \mathrm{~cm}$ depth with $\mathrm{TL}=$ Release rate $[\mathrm{PT}]=$ sediment PT concentration and $\mathrm{LOI}=\%$ of organic matter in sediment.

$\mathrm{FA}_{\text {estimated }}=-36.2+50.1 \times \log \left[\mathrm{PT}_{\text {epi }}\right]+0.762$ $\mathrm{x} \mathrm{Z} / \mathrm{Ao}^{0.5}$, with $\mathrm{AF}=$ Anoxic Factor. 
$\mathrm{Z}=$ Mean depth, $\mathrm{Ao}=$ Surface of lagoon, $\left[\mathrm{PT}_{\mathrm{epi}}\right]$ $=$ epilimnetic $\mathrm{PT}$ concentration.

This equation applied to the lagoon PortoNovo during GSS produce the graph of Figure 11. Means depths allowed establishment of isobaths curves as presented in Figure 12. Correlation coefficients between sediment organic phosphorus, total phosphorus, organic matter content, water chlorophyll a and transparency allowed us validating the above mentioned Nürnberg equations (Table 5).

Graph presented on Figure 11 shows PT variation according to $\mathrm{TL}$, whereAF represents an estimated factor. The regression equation of this variation is the following:

$\mathrm{Y}=16.44 \mathrm{X}+5348.3$ with correlation coefficient $\mathrm{R}^{2}=0.98$ (1)

$\mathrm{Y}=$ sediment $\mathrm{PT}$ concentration and $\mathrm{x}=$ Phosphorus internal load (TLxFA).

This equation becomes:

$\mathrm{PT}=16.44(\mathrm{FAxTL})+5348.3(2)$

$\mathrm{TL}=\frac{-5348,3+P T}{16,44 F A}$ ou $\mathrm{TL}=\frac{-5348.3}{16,44 F A}+\frac{P T}{16.44 F A}(3)$

The following estimations derive from those equations:

Release rate (TL): $11.05 \mathrm{mg}^{*} \mathrm{~m}^{-2} *_{\mathrm{j}}^{-1}$

Phosphorus internal load: $156.03 \mathrm{mg}^{*} \mathrm{~m}^{-2 *}$ season $^{-1}$

The low average depth of the lagoon PortoNovo $(166 \mathrm{~cm})$ prevents establishment of any thermal stratification as well as conditions for a veritable anoxia. Water residence time (18.04 minutes) is not of nature to present repercussions on its quality. Conversely, PT average mean over the whole study period and all the sites investigated taken together is showing that PT is highly concentrated in sediments. Apart from GSP, PT concentration in sediments decreases from site S1 to S2 suggesting that external supplies in phosphorus should be linked to soil leaching from slope basin, e.g. from continental origin. Hou et al., (2013) achieved with the same conclusion on Dailai Lakein Northwest China. This observation is justified also by the very high water PT concentration at S1 when compared with all other sites excepted during the GSS (Figure 4). Sediment PT concentration in S4 is relatively high due to hydrodynamic conditions reigning at this level of the lagoon. Hence, S4 is located in an area which profile shows decreasing depth into the exit of the lagoon (Figure 11). High depth allows waters to be more calm increasing thus sedimentation, productivity and organic matter mineralization phenomenon, and sets then a control upon chemical element repartition including phosphorus (Taoufik et al., 2005). Detrital sedimentation takes place upstream S4 in relatively deep zones from alluvial sediments arising from Western sides of the lagoon, notably from Ouémé River. Those sediments are contemporary, well known by sand handlers, who are able to discriminate them from older depots. This detrital sedimentation may be accompanied by that of phosphorus removed in suspension, trained by water flow into new depot downstream. All happen regarding phosphorus as a series of sedimentations and restorations in suspension, provoking nutrient accumulation towards exiting part at S4, witnessed by sediment phosphorus concentration increment in S4 reported to S3.

P-labile fraction is considered as the unique form preferentially and directly equitable by algae (Reynolds, 1984). More than its assimilation by those organisms, P-labile can also be retained by adsorption, complexation 
and precipitations reducing its presence in waters (Ormaza Gonzales and Statham, 1991; Stumm and Morgan, 1996). In lagoon PortoNovo, its rate ranges from 0.44 to $14.75 \%$ PT in sediments, very low compared to other phosphorus fractions. Similar observations have been made by Pourriot and Meybeck (1995) stating that such rate is inferior to $1 \%$ in sediments. It is lower than $0.005 \%$ in lake Naine (Labrecque, 2012).

Phosphorus fraction bound to iron (P-Fe) results from phosphate anion fixation on iron oxides. Adsorption mechanisms and their incidence on surface properties of oxides are well known (Barrow, 1970; Hingston et al., 1974; Parfitt et al., 1975; Wann and Uehara, 1978). Fortin et al., (1993) demonstrated that ferridhydrite and lepidocrocite are the most important iron oxihydroxides in many lakes that make easier phosphate ion adsorption. Goethites are other iron oxihydroxides which adsorption on phosphate ions has raised much attention (Sigg and Stumm, 1980; Stumm et al., 1980; Goldberg and Sposito, 1984; Hawke et al., 1989; Nilsson et al., 1992; Lumsdon and Evans, 1994). These elements arise from ferralitic soils also called 'Terre de barre' of theslope under-basin on which the town Porto-Novo is built (Alassane, 2004). Phosphate adsorption thanks surface properties induced by oxides needs compensating ions such as $\mathrm{Na}^{+}$. According to Hawke et al., (1989), humic substances $\left(\mathrm{Mg}^{2+}, \mathrm{SO}^{2-}\right)$ reduce phosphate ion adsorption on goethite. Sediment richness in silt and its relatively high $\mathrm{Mg}^{2+}$ concentration (Table 2) may result in the low P-Fe form observed in sediments at stations $\mathrm{S} 2$ and $\mathrm{S} 4$ rich in silt and loam. P-Fe is the most available phosphorus fraction, sensitive to $\mathrm{pH}$ and $\mathrm{rH}$ variations (Böstrom, 1984; Skovgaard and Thamdrup, 1993; Kuma et al., 1996). Christophoridis and Fytianos (2006) observed that $\mathrm{P}-\mathrm{Fe}$ is sensitive to redox potential reduction, and can be released after susjacent water anoxia. $\mathrm{pH}$ variation to 5 and 9 shows that $\mathrm{P}-\mathrm{Fe}$ is more released at $\mathrm{pH} 9$ than 5 on sediments of the lagoon Porto-Novo. This result can be elucidated by the phosphate ion adsorption capacity on iron oxihydroxide surface. Hence, according to Stumm (1992), stressed by Gomez 1999, whenever iron oxihydroxide surface is exposed to aqueous environment, it is covered by hydroxyl groupings. Fe (III) ions at the surface bind water molecules which dissociate in $-\mathrm{OH}$ groups amphoters. From there, they can either capture a proton and acquire a positive charge, or lose a proton and become negatively charged. Global charge of iron hydroxide results mainly from proton transfer on the surface, and depends upon therefore $\mathrm{pH}$. Iron atom bound to hydroxyl group can exchange its $-\mathrm{OH}$ group against $\mathrm{PO}_{4}^{-3}$ (Martin and Smart, 1987).pH variations facilitate P-Fe complex release. Basic $\mathrm{pH}$ by stabilizing proton transfer may facilitate this release moreover.

Phosphorus fraction bound to Calcium (P-Ca) is the main path of phosphorus storage in sediments (Goltermanet al., 1998; Kozerski and Kleeberg, 1998). This fraction has been considered for a long time as non mobilizable. Nowadays, P-Ca, P-Fe as well as P-labile are known as also mobilizable (Taoufiket al., 2005). In sediments of the lagoon PortoNovo, it may arise from phosphorus atom fixation on $\mathrm{CaCO}_{3}$ issued from shell sedimentation of chalk organisms after their death, given that many chalk shell mollusk and crustaceans constitute the main invertebrate fauna in the lagoon Porto-Novo (Adandédjan, 2011). Reports from particle size analysis revealed in the first two stratums an existence of many gastropod and lamellibranches shells. P-Ca is evaluated as $1.63 \%$ PT. $\mathrm{pH}$ variation on sediments under study shows that the $\mathrm{pH}$ drop (around $\mathrm{pH} 5$ ) leads to the decrease in $\mathrm{P}-\mathrm{Ca}$ rate in accordance with previous observations made 
by Boers (1991), Böstrom et al., (1988), Eckert et al., (1997). Furthermore, pH increase has favorite $\mathrm{P}-\mathrm{Ca}$ precipitation leading to its augmentation in sediments sampled in the area of study as earlier observed by Dittrich et al., (2000) and Lopez and Morgui (1992) in artificial experiments and a coastal lagoon, respectively.

Phosphorus fraction bound to Aluminium (P$\mathrm{Al})$ in the lagoon Porto-Novo ranges from $17.95 \pm 8.24 \mu \mathrm{g} / \mathrm{g}$ to $48.73 \pm 10.95 \mu \mathrm{g} / \mathrm{g}$. Such low rate $(2.19 \% \mathrm{PT})$ in sediments is comparable to earlier reports made by Mama in Lake Nokoué (Mama, 2010). P-Al fraction sources from ion phosphate $\left(\mathrm{PO}^{3-}\right)$ fixation on aluminium particles. $\mathrm{PH}$ diminution reported to average experimental one or in contrast its augmentation provokes $\mathrm{P}-\mathrm{Al}$ release in accordance with the work of Tometin (2008).

Phosphorus fixed in organic matter (P-Org) out of the survey in lagoon Porto-Novo reaches proportions ranging from $452.6 \pm 53.50 \mu \mathrm{g} / \mathrm{g}$ to $2035.4 \pm 311.2 \mu \mathrm{g} / \mathrm{g}$. POrg content in organic matter variation from a season to another seems to be related to the complexation of phosphate ions on organic matter and to a hydro-sedimentological phenomenon. Hence, correlation between POrg and organic matter loaded in sediments contents (Table 3) during dry periods (GSS and PSS) shows relatively high coefficients, $\mathrm{R}=0.414 \quad(\mathrm{p}=0) \quad$ and $\mathrm{R}=0.731 \quad(\mathrm{p}=0.269)$, witnessing certain relationship among P-Org formation and organic matter sedimentation. The high content in this phosphorus fraction compared to others is the consequence on the one hand of organic matter accumulation arising from the slope bowl through diverse anthropoid activities such as agriculture, animal husbanding, etc., and on the other hand the effects of plant and animal organic matters present on the lagoon. Plant biomass contains indeed organic phosphorus essential for their metabolism. Algal cell content in phosphorus is largely variable while that of bacteria in similar conditions is any case five to ten times richer (Brussaard and Riegman, 1998; Stenzel et al., 2017). According to Lukkari et al., (2007), P-Org availability from its builders hinges upon the size and stability of molecules in opposition to hydrolysis, and besides to degradation processes linked to microbial activities and environmental conditions such as $\mathrm{pH}$. Sediment organic phosphorus is mainly under monoester and diester orthophosphate form (Ingall et al., 1990). It is also well known that lake sediments are rich in polyphosphates synthesized and stored as inorganic granules in microbial cells (Hupfer et al., 1995). After cell death, phosphorus is rapidly released by autolysis. Brock and Schulz-Vogt (2011) testing phosphate release to anoxia and high concentration of acetate found out that increasing anoxia resulted in a decomposition of polyphosphate. Theseauthors concluded that such physiological reaction provides a new explanation for high phosphate concentration in marine sediment. These results are enough similar to our observations in Porto-Novo lagoon.

P-resid is considered as very difficult mobilizable from sediments owing to the fact that its extraction needs very energetic treatments (Taoufik et al., 2004), and after Mesnage (1994) and Golterman et al., (1998), this fraction can be mineralized only by intense bacterial activity. Its relatively high rate in sediments meet in the lagoon PortoNovo is indicating the weakness of bacterial activities inside.

Phosphorus release rate (TL) recorded $(11,05$ $\left.\mathrm{mg} * \mathrm{~m}^{-2} * \mathrm{j}^{-1}\right)$ is over the value indicated by Labrecque et al., (2012) in lake Naime (4 $\left.m{ }^{*} m^{-2} * j^{-1}\right)$. Nürnberg and Lazerte (2004) cited by Labrecque et al., (2012) stated that $\mathrm{TL}$ values comprised between $2-7 \mathrm{mg}^{*} \mathrm{~m}^{-2} * \mathrm{j}^{1}$ are relevant to mesotrophic lakes. Such a rate is signaling that the lagoon Porto-Novo is in 
an eutrophic state during the season considered with an internal loading estimated at $156,03 \mathrm{mg}^{*} \mathrm{~m}^{-2} *$ saison $^{-1}$. More concretely, phosphorus weight loaded in the lagoon during the dry season and able to be released unidirectional into the water column is in the range of $5.461 .050 \mathrm{~kg}$, being 5.461 tons. An elevated phosphorus load is revealed in this lagoon (resulting probably from many years and seasons sedimentation process) and should be even higher omitting lagoon sand exploitation activities starting by scraping down the first centimeters of the lagoon bottom. Nonetheless, that activity may induce elsewhere phosphorus release into the water column, followed by its sedimentation with the consequence of hardening any evaluation process of phosphorus internal load.

Impact of phosphorus internal loads on the water quality depends on the availability in this mineral element. Study on phosphorus bioavailability showed certain variability of its different existing forms according to environment properties. Zhang et al., (2015) studied impacts of lake water environmental conditions on bioavailable phosphorus of surface sediments. They reported that bioavailable phosphorus fraction of the lake surface sediments $(0-5 \mathrm{~cm}$ depth $)$ under investigation and environmental indicators of the related water column in five lakes in Lixia River basin in China during three seasons, varied significantly in the different seasons. High intensity of bacterial activities combined with that of algae density as well as dissolved oxygen enhanced bioavailable phosphorus rate and contributed significantly to the eutrophication of the lake, especially in summer. In the lagoon Porto-Novo, as described above, the same phenomenon is observed during the dry season (GSS November-December) corresponding at least partly to the summer under temperate climates. Mobilizable phosphate, e.g. available for algal growth (P-labile, P-Fe, P$\mathrm{Ca}$, P-Org) represents in average about
$66.39 \%$ PT. This rate is relatively lower compared to the reports of Ruban et al., (1996) in the reserve of Bort-les-Orgues in France, and in the slope basin of Oum Rabiaa (Maroc) rounding 80\%. Their observations may be justified by the reigning hydrodynamic conditions. However, it is sufficient to cause symptoms of eutrophication. Water swellings which mobilize sediments can move in suspension nutrients previously fixed (Oraisonet al., 2011). Inside stratified lakes, meteorological conditions can lead partly to the interannual variability of phosphorus dynamics in the epilimnion. The non-existence of a veritable thermal stratification within the lagoon PortoNovo is moreover a parameter that may speed down phosphorus sedimentation in the watershed analyzed.

High phosphorus release may favorite enrichment of the water column in phosphorus, algal biomass augmentation and consequently a reduction of transparency (Labrecque et al., 2012). In the watershed studied, GSS registered lower mean values in chlorophyll a and transparency, contrasting with sediment phosphorus content and its release rate in that period particularly concerning chlorophyll a, while $\mathrm{rH}$ is reducer. That situation should be explained by an adaptive reaction among phytoplankton and its biotope rendering the environment reducer.

Phosphorus that accumulates in sediments within the lagoon Porto-Novo arises from two main sources: slope bowl supplies and biological activity happening inside the watershed. It is more accumulated in the first stratums of sediments and under given conditions, it is moved in suspension increasing available phosphorus concentration in water. Consequently, eutrophication of the lagoon is observed. The current study showed that different fractions contribute to the phosphorus loading in this lagoon, and mobilizable phosphorus rate reaches $66.39 \%$ 
of total phosphorus measured. Among those fractions, P-Org is more abundant, consequence of organic matter accumulation sourcing from the slope bowl through anthropoid activities and moreover from plant and animal organic matters present on the watershed. Phosphorus release rate estimated in dry season is indicating that the lagoon Porto-Novo remains in more or less degraded state needing from local and national stakeholders and other authorities urgent actions insight a reduction of phosphorus, notably that arising from the slope basin.

\section{Acknowledgements}

The authors are deeply acknowledged to Dr. W. Chitou for valuable advises and assistances during field surveys and chemical analysis. All others anonymous at the International Chair of Mathematical Physics and Applications (ICMPA) - University Abomey-Calavi are well thanked for any encouragement during the study.

\section{References}

Achat, D. 2009. Biodisponibilité du phosphore dans les sols landais pour les peuplements forestiers de pin maritime.Thèse de doctorat, Université de bordeaux 1, Ecole doctorale Sciences et Environnements, 291p.

Adam, K. and Boko, M. 1993. Le Bénin. Les éditions du Flamboyant/Sodimas/Edicef, Cotonou, République du Bénin, 96p.

Adandédjan, D.2011. Diversité et déterminisme des peuplements de macroinvertébrés benthiques de deux lagunes du Sud- Bénin : la Lagune de Porto-Novo et la Lagune Côtière. Thèse de doctorat, Université d'AbomeyCalavi, $240 \mathrm{p}$.

AFNOR, 1984. Qualité des sols, AFNOR Edition,ISBN: 978-2-12-213171-8.

AFNOR, 1994. Qualité des sols, AFNOR Edition, $250 \mathrm{p}$.

Akogbéto, H. 2012. Indicateurs de risque et degré d'eutrophisation de la lagune de Porto-Novo. Master of Science, 69p.

Alassane, A. 2004. Etude hydrogéologique du continental terminal et des formations de la plaine littorale dans la région de Porto-Novo (Sud du Bénin): identification des aquifères et vulnérabilité de la nappe superficielle. Thèse de doctorat de troisième cycle, $145 \mathrm{p}$.

Barrow, N.J. 1970. Comparison of the adsorption of molybdate, sulphate, phosphate in soils. Soil Science, 109: 282-288.

Boers, P. 1991. The influence of $\mathrm{pH}$ on phosphate release from the lake sediments. Water Res., 25(3):309-311.

Bootsma, M.C., Barendregt A. and Van Alphen J.C.A. 1999. Effectiveness of reducing external nutrient load entering a eutrophicated shallow lake ecosystem in the Naardermeer nature reserve. The Netherlands Biol. Conserv.,90:193-201.

Böstrom, B. 1984. Potential mobility of phosphorus in different types of lake sediment. Int. Rev. Ges. Hydrobiol, 69: 457474.

Böstrom, B., Andersen J.M, Fleischer S. and Jansson M. 1988. Exchange of phosphorus across the sediment-water interface. Hydrobiologia, 170:229-244.

Brock, J. and Schulz-Vogt, H.N. 2011. Sulfide induces phosphate release from polyphosphate in cultures of a marine Beggiatoa strain. International Society for Microbial Ecology, 5: 497-506.

Brussaard, P.D. and Riegman, R. 1998.Influence of bacteria on phytoplankton cell mortality with phosphorus or nitrogen as the al-growthlimiting nutrient. Aqua. Microb. Ecol., 14: 271-280.

Chitou, W., Mama, D., Alassane, A., Changotade, O., Alapini, F., Boukari, M., Aminou, T. and Afouda, A. 2011. Caractérisation physicochimique de la lagune de Porto-Novo (Sud-Bénin) et mise en relief de la pollution par le mercure, le cuivre et le zinc. Journal of Applied Biosciences, 43: 2882 - 2890 ISSN 1997-5902.

Christophoridis, C. and Fytianos, K. 2006. Conditions affecting the release of phosphorus from surface lake sediments. J. Environ. Qual., 35: 1181- 1192.

Craaq. 2008.La mobilité du phosphore du sol au cour d'eau, fiche technique $n^{\circ} 1,12 p$.

Dittrich, M., Casper, P., and Koschel, R. 2000. Changes in the pore water chemistry of 
profundal sediments in response to artificial hypolimnetic calcite precipitation. Arch.Hydrobiol. Spec. Issues Advanc. Limnol., 55:421-432.

Eckert, W., Nishri, A., and Parparova, R. 1997. Factors regulating the flux of phosphate at the sediment - water interface of a subtropical calcareous lake: a simulation study with intact sediment cores. Water Air Soil Pollut., 99:401-409.

Fortin, D., Leppard, G.G, and Tessier, A. 1993. Characteristics of Lacustrine Diagenetic Iron Oxyhydroxides. Geochimica et Cosmochimica Acta, 57: p.4391-4404.

Gachter, R. and Meyer, J. S. 1992.The role of microorganisms in mobilization and fixation of phosphorus in sediments. Hydrobiology, 253p.

Gerdes,P. and Kunst, S. 1998. Bioavailability of phosphorus as a tool for efficient $\mathrm{P}$ reduction schemes. Water Sci. Technol, 37(3):241-247.

Goldberg, S. and Sposito, G. 1984. A Chemical Model for Phosphate Adsorption by Soils: 1. Reference Oxide MineraIs. Soil Sci. Soc. Am. J., 48: p.772-778.

Golterman, H. L. 2004a. The chemistry of phosphate and nitrogen compounds in sediments. Kluwer Academic Publishers, Boston, MA, États- Unis, 251 p.

Golterman, H. L. 2004b. The distribution of phosphate over iron-bound and calcium-bound phosphate in stratified sediments. Hydrobiologia, 364:75-81.

Golterman, H.L., Paing, J., Serrano, L. and Et al., E.1998. Presence of and phosphate release from polyphosphates or phytate phosphate in lake sediments. Hydrobiologia, 364:99-104.

Gomez, E.,Durillon, C., Rofes, G., and Picot, B. 1999. Phosphate adsorption and release from sediments of brackish lagoons: $\mathrm{pH}, \mathrm{O} 2$ and loading influence. Water Res., 33:2437-2447.

Hawke, D., Carpenter, P. D., and Hunter, K. A. 1989. Competitive Adsorption of Phosphate on goethite in Marine Electrolytes. Environ. Sci. Technol., 23: p.187-191.

Hieltjes, A.H.M. and Lijklema, L. 1980. Fractionation of inorganic phosphate in calcareous sediments. J. Environ. Qual., 9:405-407.

Hingston, F.J., Posner, A. M. and Quirk, J. P. 1974. Anion adsorption by gœthite and gibbsite. 1. Desorption of anions from hydrous oxide surfaces. J. Soil Science, 25, 16-26.

Hou, D., He, J., Lü, C., Sun, Y., Zhang, F. and Otgonbayar, K. 2013.Effects of Environmental Factors on Nutrients Release at Sediment-Water Interface and Assessment of Trophic Status for a Typical Shallow Lake, Northwest China. The Scientific World Journal, 1-16.

Hupfer, M., Gächter, R. and Rüegger, H. 1995. Polyphosphate in lake sediments: 31P NMR spectroscopy as a tool for its identification. Limnol. Oceanogr., 40: 610-617.

Ingall E.D., Schroeder P.A. and Berner R.A. 1990. Characterization of organic phosphorus in marine sediments by31P NMR. Geochemistry of the Earth's Surface and of Mineral Formation. 2nd International Symposium, July 2-8,p. 220-223.

Jensen, H.S., Kristensen, P., Jeppesen, E. and Skytthe, A. 1992. Iron phosphate ratio in surface sediment as indicator of phosphate release from aerobic sediments in shallow lakes. Hydrobiologia, 235/236: 731-743.

Kaiserli A., Voutsa, D. and Samara, C. 2002. Phosphorus fractionation in lake sedimentslakes Volvi and Koronia, N-Greece. Chemosphere 46:1147-1155.

Kozerski, H.P. and Kleeberg, A. 1998. The sediment and the benthic pelagic exchange in the shallow lake Muggelsee. Int. Rev. Hydrobiol., 83:77-112.

Kuma, K., Nishioka, J. and Matsanaga, K. 1996. Controls on iron (III) hydroxide solubility in seawater: the influence of $\mathrm{pH}$ and natural organic chelators. Limnol. Oceanogr. 41(3):396-407.

Labrecque, V., Nürnberg, G., Tremblay, R. and Pienitz, R. 2012. Caractérisation de la charge interne de phosphore du lac Nairne, Charlevoix (Québec). Revue des sciences de l'eau / Journal of Water Science, 25(1): 77-93.

Lopez, P. and Morgui, J.A. 1992. Phosphate and calcium carbonate saturation in a stratified coastal lagoon. Hydrobiologia, 228: 55-63.

Lukkari, K., Hartikainen, H. and Leivuori, M. 2007. Fractionation of sediment phosphorus revisited. I: Fractionation steps and their biogeochemical basis. Limnol. Oceanogr. Methods, 5: 433-444.

Lumsdon, D.G. and Evans, L. 1994. Surface 
Complexation Model Parameters for goethite (a-FeOOH). Journal of Colloid and Interface Science, 164: 119-125.

Mama, D. 2010. Méthodologie et résultats du diagnostic de l'eutrophisation du lac Nokoué (Benin). Thèse de doctorat, Université de Limoges, p. 157.

Martin, R.R. and Smart, R.S. 1987. X-ray Photoelectron Studies of Anion Adsorption on goethite. Soil Sci. Soc. Am. J., 51: p.54-56.

Mesnage, V.1994. Etude de la mobilité des formes de phosphate à l'interface eau - sédiment dans les écosystèmes lagunaires. Thèse de Doctorat, Université Montpellier II, France. $253 \mathrm{p}$.

MINITAB. 2014. Release 14. Minitab Inc., USA, ISBN 0-925636-48-7.

Mortimer, C.H. 1941. The exchange of dissolved substances between mud and water in lakes $I$. J. Ecol., 29:280-329.

Nilsson, N., Lôvgren, L. and Sjôberg, S. 1992. Phosphate Complexation at the Surface of goethite. Chem. Speciation Bioavail., 4: 121130.

Nürnberg, G.K. 1988. Prediction of phosphorus release rates from total and reductant- soluble phosphorus in anoxic lake sediments. Can. J. Fish. Aquat. Sci., 45: 453- 462.

Nürnberg, G.K. 1996. Trophic state of clear and colored, soft- and hardwater lakes with special consideration of nutrients, anoxia, phytoplankton and fish. Lake Reserv. Manage, 12: $432-447$.

Nurnberg, G.K. 2009. Assessing internal phosphorus load- Problems to be solved. Lake Reserv. Manage., 25: 419 - 432.

Nürnberg, G.K. and Lazerte, B.D. 2004.Modeling the effect of development on internal phosphorus load in nutrient- poor lakes. Water Resour. Res., 40: 1- 9.

Oraison, F., Souchon, Y., Looy, K.V. 2011. Restaurer l'hydro-morphologie des cours d'eau et mieux maîtriser les nutriments : une voie commune, $42 \mathrm{p}$.

Ormaza Gonzales, F.I. and Statham, P.J. 1991. The occurrence and behaviour of different forms of phosphorus in the waters of four English estuaries. In Elliott M, Ducrotoy JP (ed.), Estuaries and coasts: spatial and temporal inter comparisons. Olsen and Olsen, London. $77-83$ p.
Parfitt, R.L., Atkinson, R.J. and Smart, R.C. 1975. The mechanism of phosphate fixation by iron oxides.Soil Sci. Soc. Amer. Proc., 39: 837841.

Pienitz, R. and Vincent, W.F. 2003. Generic approaches towards water quality monitoring based on paleolimnology. Dans: Freshwater Management - Global versus Local Perspectives, Kumagai M.and Vincent W F (Éditeurs), pp. 61- 82, Springer- Verlag, Tokyo/Berlin..

Pourriot, R. and Meybeck, M. 1995. Limnologie générale. Masson, Paris, France, 956 p.

Psenner, R., R. Pucsko, and Sager, M. 1984. Die Fraktionierung organischer und anorganischer Phosphorverbindungen von Sedimenten. Versuch einer Definition ökologisch wichtiger Fraktionen. [Fractionation of organic and inorganic phosphorus compounds in lake sediments: an attempt to characterize ecologically important fractions.] Arch. Hydrobiol., 70(Suppl. 1):111-155.

Reddy, K.R., Kadlec, R.H., Flaig, E. and Gale, P.M. 1999. Phosphorus retention in streams and wetlands: a review. Crit. Rev. Environ. Sci. Technol.,29:83-146.

Reynolds, C.S. 1984. The ecology of freshwater phytoplancton. Beck E (ed.), Cambridge University Press.

Ruban, V., Demare, D. and Fournier, A. 1996. Potentialités de relargage du phosphore dans la retenue hydroélectrique de Bort-les-Orgues Bulletin des laboratoires des ponts et chaussées - 210 - Juillet-Août 1997 - Réf. 4131 - PP. 87-93.

Ruban, V., López-Sánchez, J.F., Pardo,P., Rauret,G., Muntau,H., and Quevauviller,Ph. 1999. Selection and evaluation of sequential extraction procedures for the determination of phosphorus forms in lake sediment. $J$. Environ. Monit. 1:51-56.

Rydin, E. 2000. Potentially mobile phosphorus in Lake Erken sediment. Water Res., 34(7):2037-2042.

Rydin, E. and Burnberg, A. 1998. Seasonal dynamics of phosphorus in Lake Erken surface sediments. Arch. Hydrobiol. Spec. Issues Advanc. Limnol., 51:157-167.

Rydin, E. and Welch, E.B. 1998. Aluminum doses require to inactivate phosphate in lake sediments. Water Res. Water Research, 32; 
Elsevier Science Ltd, Pergamon, 8p.

SAS. 2007. JMP. User guides. SAS Institute, Inc., NC, USA.

Sigg, L. and Stumm, W. 1980. The Interaction of Anions and Weak Acids with the Hydrous goethite (a-FeOOH) Surface. Colloïds and Surfaces, 2: 101-117.

Skovgaard, H. and Thamdrup, B. 1993. Iron bound phosphorus in marine sediments as measured by bicarbonate - dithionite extraction. Hydrobiologia, 253:47-59.

Smith, V.H., Tilman, G.D. and Nekola, J.C. 1999. Eutrophication: impacts of excess nutrient inputs on freshwater, marine, and terrestrial ecosystems. Environmental Pollution, 100: 179-196.

Sondergaard, M., Jensen, J.P. and Jeppesen, E. 2003. Role of sediment and internal loading of phosphorus in shallow lakes. Hydrobiologia, 506-509:135-145.

Stenzel, B., Rofner, C., Pérez, M.T. and Sommaruga, R. 2017.Stoichiometry of natural bacterial assemblages from lakes located across an elevational gradient. Scientific Reports, DOI:10.1038/s41598-017-06282-0.

Stumm W, Kummert R, Sigg L. 1980. A Ligand Exchange Model for the Adsorption of Inorganic and-Organic Ligands at Hydrous Oxide Interfaces. Croat. Chem. Acta, 53: 291312.

Stumm, W. 1992. Electrified Interfaces in Physics, Chemistry and Biology: The Solid Electrolyte Interface as Exemplified by Hydrous Oxides; Surface Chemistry and Surface Reactivity. Pays-Bas, Kluwer Academic Publishers, p.443-472.

Stumm, W. and Morgan, J.J. 1996. Aquatic chemistry (3rd edition), Wiley-Interscience Publication, New York.

Tailling, J.F. 1957. Photosynthctic characteristics of some freshwater plankton diatoms in relation to underwater radiation. New Phytol., 56: 29-50.

Taoufik, M., Dafir, J.E., Kemmou, S. 2005. Hydrogeochemical Behaviour of Phosphorus in the Imfout Reservoir (OumRabiaa, Morocco). Res. J. Canada, 40(2): 202-210.

Taoufik, M., Kemmou, S.,Loukili Idrissi, L. and Eddine Dafir, J.2004. Comparison of Two Methods for the Fractionation of Phosphorus from Sediments of the Lower Oum Rabiaa Basin (Morocco).Water Qual. Res. J. Canada, 39(1): 50-56.

Tometin, S. 2008. Etude de la biodisponibilité et de la mobilité du phosphore des sédiments responsable du phénomène d'eutrophisation du lac Nokoué.Mémoire d'obtention du DEA, faculté des sciences et techniques, formation Doctorale Chimie et Application (UAC) ; $116 \mathrm{p}$.

Wann, S.S. and Uehara, G. 1978. Surface charge manipulation of constant surface potentiel soil colloïdes. Relation to sorbedphosphorus. Soil Science Soc. Amer. Proc., 42: 565-569.

Wetzel, R.G. 2001. Limnology, Lake and River Ecosystems, third edition. Elsevier, Academic Press. California, USA. 1006 p.

Williams, J.D.H., Jaquet, J.M. and Thomas, R.L. 1976. Forms of phosphorus in the surfacial sediments of lake Erie. J. Fish. Res. Board Canada, 33:413-429.

Zhang, Y., Liu L. and Lu, C. 2015. Impacts of lake water environmental condition on bioavailable phosphorus of surface sediments in Lixia River basin, China. Remote Sensing and GIS for Hydrology and Water Resources (IAHS Publ.), 368: 424-429.

\section{How to cite this article:}

Henri Kpèdékpo Akogbeto, Ahissou Séraphin Zanklan, Edmond Sossoukpe and Emile Didier Fiogbe. 2017. Fractionation of Sediment Phosphorus in Lagoon Porto-Novo (Benin Republic) Revisited: Changes in Phosphorus Fractions and Release as Affected by Seasons and Sampling Sites. Int.J.Curr.Microbiol.App.Sci. 6(11): 2914-2937.

doi: https://doi.org/10.20546/ijcmas.2017.611.344 